\title{
Review
}

\section{New Trends in Nanoclay-Modified Sensors}

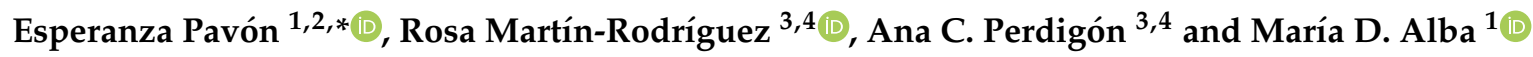 \\ 1 Instituto Ciencia de los Materiales de Sevilla, CSIC-Universidad de Sevilla, Avda. Américo Vespucio, 49. \\ 41092 Seville, Spain; alba@icmse.csic.es \\ 2 Departamento Física de la Materia Condensada, Universidad de Sevilla, Av. Reina Mercedes s/n, \\ 41012 Seville, Spain \\ 3 Departamento QUIPRE, Universidad de Cantabria, Avda. de Los Castros 46, 39005 Santander, Spain; \\ rosa.martin@unica.es (R.M.-R.); anacarmen.perdigon@unican.es (A.C.P.) \\ 4 Grupo de Nanomedicina, IDIVAL, Avda. Cardenal Herrera Oria s/n, 39011 Santander, Spain \\ * Correspondence: epavon@us.es; Tel.: +34-954-48-9546
}

Citation: Pavón, E.;

Martín-Rodríguez, R.; Perdigón, A.C.; Alba, M.D. New Trends in

Nanoclay-Modified Sensors.

Inorganics 2021, 9, 43. https://

doi.org/10.3390/inorganics9060043

Academic Editor: Antonino Gulino

Received: 11 May 2021

Accepted: 28 May 2021

Published: 2 June 2021

Publisher's Note: MDPI stays neutral with regard to jurisdictional claims in published maps and institutional affiliations.

Copyright: (C) 2021 by the authors. Licensee MDPI, Basel, Switzerland. This article is an open access article distributed under the terms and conditions of the Creative Commons Attribution (CC BY) license (https:/ / creativecommons.org/licenses/by/ $4.0 /)$.

\begin{abstract}
Nanoclays are widespread materials characterized by a layered structure in the nano-scale range. They have multiple applications in diverse scientific and industrial areas, mainly due to their swelling capacity, cation exchange capacity, and plasticity. Due to the cation exchange capacity, nanoclays can serve as host matrices for the stabilization of several molecules and, thus, they can be used as sensors by incorporating electroactive ions, biomolecules as enzymes, or fluorescence probes. In this review, the most recent applications as bioanalyte sensors are addressed, focusing on two main detection systems: electrochemical and optical methods. Particularly, the application of electrochemical sensors with clay-modified electrodes (CLME) for pesticide detection is described. Moreover, recent advances of both electrochemical and optical sensors based on nanoclays for diverse bioanalytes' detection such as glucose, $\mathrm{H}_{2} \mathrm{O}_{2}$, organic acids, proteins, or bacteria are also discussed. As it can be seen from this review, nanoclays can become a key factor in sensors' development, creating an emerging technology for the detection of bioanalytes, with application in both environmental and biomedical fields.
\end{abstract}

Keywords: nanoclays; sensor; electrochemical; optical; biosensors; bioanalytes

\section{Introduction}

\subsection{Nanoclays: Definition and Classification}

Nanomaterials' definition is still controversial, and scientists have not unanimously settled on a precise denotation, although there is consensus that they are partially characterized by their tiny size, in the range of nanometers. In 2011, in order to clarify this debate, the EU adopted the following definition for a nanomaterial: "a natural, incidental or manufactured material containing particles, in an unbound state or as an aggregate or as an agglomerate and where, for $50 \%$ or more of the particles in the number size distribution, one or more external dimensions is in the size range $1 \mathrm{~nm}-100 \mathrm{~nm}^{\prime \prime}$ [1]. Among the first natural nanomaterials known, according to this definition, are nanoclays, which have been used since historical times.

Nanoclays are a broad class of natural or synthetic clay minerals with at least one dimension in the nano-range order, as defined by the EU [1] and characterized by a layered structure. They can be divided into three main classes, according to their electrochemical charge (Table 1 and Figure 1).

- Neutral nanoclays do not possess any charge in their layers. Commonly, their layers are formed by two tetrahedral sheets that sandwich one octahedral sheet (2:1 nanoclay, pyrophyllite, and talc group) or by a tetrahedral sheet confronted with an octahedral sheet (1:1 nanoclays, kaolinite, and serpentine group). Tetrahedral sheets are formed by $\left[\mathrm{SiO}_{4}\right]^{-4}$ ions while octahedral sheets are formed by $\mathrm{Mg}^{+2}$ or $\mathrm{Al}^{+3}$ complex. 
- Cationic nanoclays have negatively charged layers. Two main groups can be found into this category, 2:1 and 2:1:1 nanoclays. The first one is formed by the same sheet configuration previously described for neutral 2:1 nanoclays. The most common minerals on the Earth's surface can be found in this group: smectites, vermiculites, micas, and brittle micas. The second group is formed by stacking an octahedral sheet between a 2:1-layer configuration, forming the chlorite group. Negative layer charge is originated by the isomorphous substitutions that occur either in the tetrahedral $\left(\mathrm{Si}^{+4}\right.$ by $\mathrm{Al}^{+3}$ ) or octahedral sheet $\left(\mathrm{Al}^{+3} / \mathrm{Mg}^{+2}\right.$ by $\mathrm{Mg}^{+2} / \mathrm{Li}^{+}$, respectively, for example). Electrical neutrality is ensured by inorganic or organic ions in the interlayer space balancing the charge generated. When organic cations are introduced in the interlayer space, organo-nanoclays are created.

- Anionic clays are positively charged hydroxide layers, also known as layered double hydroxides (LDHs). Their layer structure (Figure 1) is based in divalent metal ions (such as $\mathrm{Mg}^{+2}$ ), forming an octahedral sheet. Commonly, these divalent cations are substituted by trivalent cations (such as $\mathrm{Al}^{+3}$ ), creating a positive charge for each aluminum substituted by magnesium ion. To maintain the electrical neutrality, anions such as $\mathrm{CO}_{3}{ }^{-2}, \mathrm{NO}_{3}{ }^{-}$, and $\mathrm{Cl}^{-}$are located in the interlayer galleries.

Table 1. Nanoclays' classification.

\begin{tabular}{|c|c|c|c|}
\hline $\begin{array}{c}\text { Type of Layer } \\
\text { Charge }\end{array}$ & Group & Layer Type & $\begin{array}{c}\text { Layer Charge } \\
\mathrm{O}_{10}(\mathrm{OH}, \mathrm{F})_{2} \text { Unit }\end{array}$ \\
\hline \multirow{2}{*}{ Neutral } & Kaolinite-serpentine & $1: 1$ & $<0.01$ \\
\hline & Pyrophyllite-Talc & $2: 1$ & 0 \\
\hline \multirow{5}{*}{ Cationic } & Smectite & & 0.2 to 0.6 \\
\hline & Vermiculite & & 0.6 to 0.9 \\
\hline & Mica & $2: 1$ & ca. 1 \\
\hline & Brittle mica & & up to 2 \\
\hline & Chlorite & $2: 1: 1$ & variable \\
\hline Anionic & $\begin{array}{l}\text { Layered double } \\
\text { hydroxide (LDH) }\end{array}$ & $0: 1$ & variable \\
\hline
\end{tabular}

a)

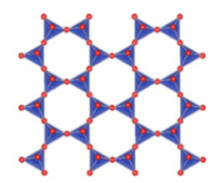

14.4M I

c)

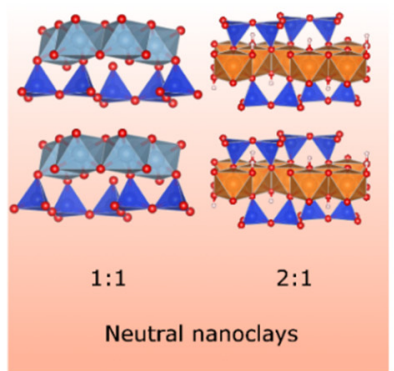

$.3 \mathrm{~nm}$

d)

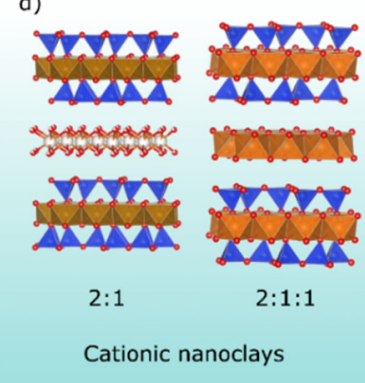

b)

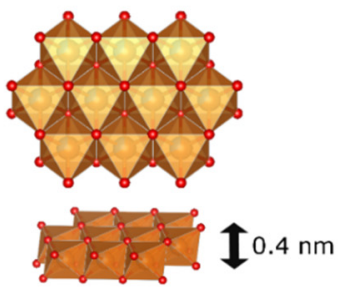

e)

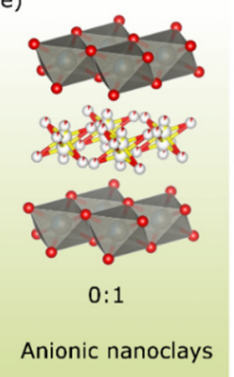

Figure 1. (a) Tetrahedral sheet; (b) octahedral sheet. Layered nanoclay structures: (c) neutral nanoclays (type 0:1 and 2:1), (d) cationic nanoclays (type 2:1 and 2:1:1), and (e) anionic nanoclays (type 0:1).

In all cases, tetrahedral or octahedral sheets have thicknesses of $0.3 \mathrm{~nm}$ and $0.4 \mathrm{~nm}$, respectively (Figure 1). 
Swelling capacity, cation exchange capacity, and plasticity are the main properties derived from the layer charge and interlayer cations that make nanoclays so useful for many applications. In fact, nanoclays, especially cationic ones, have been used for centuries in architecture, industry, and agriculture. Because they are environmentally friendly and readily available in large quantities at relatively low cost, they are nowadays applied in medical, food, and environmental fields [2].

Due to the cation exchange capacity, nanoclays can serve as host matrices for the stabilization of several molecules and, thus, they can be used as sensors by incorporating electroactive ions, biomolecules as enzymes, or fluorescence probes. The resulting nanoclaymodified electrodes (CLME) and optical sensors can be used for their electro-catalytic properties or analytical applications [3,4].

\subsection{Sensors}

A sensor is a device containing a recognition element that interacts with an analyte, leading to a chemical or physical change, which a transducer converts into a detectable signal [5]. They can be classified into several categories based on the transduction process (electrochemical, optical, piezoelectric, and thermal sensors) or according to the receptor type (enzymatic biosensors, microbial, biosensors, genosensors, or immunosensors) [6]. There is current interest in the development of different sensing systems for biomedical and environmental applications. Results in biology are usually complex, non-linear, and non-reproducible. Thus, the development of sensors with improved sensitivity and reproducibility represents an increasingly important area of research $[7,8]$. In the areas of agriculture and environment, sensors have been widely developed for the determination of pesticides, herbicides, and heavy metals in the soil and ground water, opening a new strategy for active prevention of forecast contamination.

Different types of sensing techniques can be distinguished and are addressed in this review. Firstly, electrochemical sensors are defined as integrated systems that provide quantitative or semi-quantitative analytical response thorough interactions between biochemical receptors and electrochemical transduction elements [9]. Electrochemical signal transduction can occur through the measurement of current, potential, conductance, or field effect, giving rise to voltammetry, conductometry, or impedance spectroscopy techniques. A variety of electrode materials, namely, noble metals, glassy carbon (GC), semiconductors such as indium tin oxide (ITO), or conductive polymers are available to enable specific sensing applications [5]. Electrochemical sensors have been used for detection of many different analytes that can readily be subjected to or coupled with electrochemical reactions. Several challenges must be considered in the development of sensors based on electrochemical methods. (1) The electrochemical response is usually sensitive to electrode fabrication procedures and environmental contamination, which causes non-reproducibility. (2) The use of bare electrodes usually involves slow kinetics, which limits the sensitivity. (3) The overlapping of the target analyte and concomitant compounds' signals may prevent accurate detection and selectivity [10]. Chemical modification of the bare electrodes' surface holds great potential to overcome these problems [11]. Several studies have previously reported an increase in sensitivity and selectivity toward specific target molecules by electrode modification with nanomaterials enhancing surface conductivity, such as metal nanoparticles (NPs) [12], carbon-based materials [13], organic polymers [14], or ionic liquids [15]. Electrochemical sensors are most desirable among all sensors due to their high sensitivity, experimental simplicity, and low-cost production [16].

The electrode surface modification has strong influence on the sensing performance of the electrochemical sensor [17]. Nanoclays have been applied as surface modification materials to improve the sensing performance and, since the 1990s, CLME have been extensively studied, principally, their electron transfers' phenomenon [18-21]. For example, the recent review by Goda et al. summarized the works on halloysite nanotubes' (HNTs') surface engineering and application as electrochemical sensor [22]. HNTs have been 
applied for several bioanalytes' identification, namely' hydrogen peroxide, glucose, nitrite, ascorbic acid, amines, hydrazine, dopamine, or uric acid.

Among electrochemical sensors, those based on enzymatic receptor have attracted wide attention in the biomedical and environmental fields. They can be defined as an analytical device that works on the basis of detecting an electric signal having an enzyme as a bioreceptor. They are usually named biosensors. Enzymes are biological macromolecules, proteins with catalytic activity, characterized by a high selectivity and specificity. However, the low stability of enzymes in organic solvents at widely elevated temperatures has frequently hampered the development of enzymatic biosensors [23]. To overcome this issue, the immobilization of enzymes onto organic or inorganic solid matrices has been suggested. Enzyme immobilization onto organic supports, such as polymer or organogels, has been demonstrated to satisfactorily maintain the high activity of the enzymes, but they present low thermal and chemical stability [24]. On the contrary, immobilization of enzymes on inorganic solids, such as zeolites, activated carbon, carbon nanotubes, silica mesoporous materials, and two-dimensional, layered clays, among others, results in improved activity, stability, and recyclability of the enzyme in a broader working $\mathrm{pH}$ and temperature range than the isolated enzyme $[25,26]$.

The performance of an enzymatic biosensor depends also on maintaining its catalytic action. A reduction in the dimensions of the enzyme support material generally improves the biocatalytic efficiency [27]. In this sense, due to the tiny size of their particles, large specific surface area, good absorbance ability, and high cationic exchange capacity, nanoclays are one of the most relevant material for enzyme immobilization [28], promoting greater interaction with the enzyme and reducing diffusional limitations [27]. Most clay minerals used in clay-based biosensors are smectites (laponite, montmorillonite, nontronite) and have been applied in analytical applications [16].

Nanoclays have been widely exploited for biosensor design due to their mechanical and thermal stabilities, chemical inertness, and ion exchange properties, becoming versatile and non-expensive matrices. For example, montmorillonite, a naturally occurring cationic nanoclay, is applied in a variety of electrochemical studies as CLME. By functionalization of these clay minerals with specific organic groups like amines, the resulting organic-inorganic hybrid materials show better selectivity or sensitivity. In this review, we will expose the latest electrochemical sensors based on nanoclays, used in the determination of both harmful substances to the environment, such as pesticides, and diverse biological analytes.

Secondly, optical sensors are composed of a light source, the sensing material that interacts with the analyte, and a light detector. Specifically, optical sensors based on fluorescence parameters, such as luminescence and excitation spectra, emission lifetime, or Stokes shift, can provide high flexibility and sensitivity, although the experimental apparatus might be expensive [29]. The sensing element containing the fluorescent probe must interact with the analyte and subsequently report on such interactions by the change of an optical property. Different kinds of fluorescence probes based on organic dye molecules [30], trivalent lanthanides [31], gold NPs, or semiconductor quantum dots [32] have been developed. Organic dyes usually show poor chemical stability, while quantum dots, composed of heavy metals, present toxicity and environmental hazards, which limit practical applications. On the contrary, lanthanide-based fluorescent probes present better performance, due to their low toxicity and better stability. In addition, lanthanide cations, particularly trivalent europium, $\mathrm{Eu}^{3+}$, show sharp-line emission bands, large Stokes shift, long lifetimes, and high resistance to photo-bleaching [33]. Additionally, magnetic resonance contrast agents have been the subject of extensive research in the past decade, with $\mathrm{Gd}^{3+}$ ions being the most commonly used ions for $T_{1}$-based magnetic resonance contrast enhancement [34]. In particular, colorimetric methods have recently gained attention due to their fast operation, low cost, and simplicity. They are based on the visual color change during interaction with the analytes and, thus, allow detection by immediate observation by the naked eye, without any expensive or sophisticated instrumentation. 


\section{Nanoclay-Based Sensors for Environmental Applications}

Since 1960, several types of pesticides have been widely used in agriculture due to their high activity against fungi, insects, and weeds [35]. As a result, non-target organisms are inevitably exposed to these toxic compounds that can cause damages to human health and to ecosystems [36,37]. During the past decade, works devoted to the development of electrochemical devices suitable for the detection of pesticides have gained growing interest as innovative alternatives in terms of on-site detection, sensitivity, rapid response, miniature size, and low cost. Most reported papers have been devoted to the development of CLME for the detection of herbicides (such as mesotrione, glyphosate, phenyl urea herbicides, and paraquat) $[3,20,38-41]$ and fungicides (such as propineb, chlorpyrifos, or carbendazim) [42-44].

Raw nanoclays $[20,38,40]$ and modified nanoclays with metallic cations such as $\mathrm{Cu}^{2+}$ [42] or organic cations have been tested as CLME. Among the possible organic molecules intercalated in the nanoclay interlayer, cetyltrimethylammonium (SaCTA) [20], didodecyldimethyl ammonium (SaDDA) [20], acetylcholinesterase (AChE) [43], or methyl viologen (MV) [38] are the most common ones. Moreover, nanoclays grafted with silane molecules have also been proposed as CLME [39,44]. In this case, several strategies have been employed and the properties of the grafted nanoclays depended on the nature of the solvents and the silane molecule. For example, Mbokana et al. [39] successfully modified the internal and external surface of a smectite by triethoxyoctylsilane to prepare CLME for the electroanalysis of glyphosate. The material was first submitted to a soft acid pretreatment to provide abundant and available hydroxyl groups capable of reacting with the silane. They found that silane grafting was more effective in ethylene glycol (swelling) as solvent compared to toluene (non-swelling). Also, Yanke et al. [44] investigated the effect of these two solvents on the grafting of an organophilic silane (octyltriethoxisilane) onto a smectitic clay to evaluate their abilities for electrochemical detection of organophilic pesticide. There, the grafting occurred exclusively on the edges of the clay particles without intercalation. In both cases, the material functionalized in ethylene glycol was found to be the most efficient, due to the combined effect of the characteristics of the pristine clay and the grafted silane. Those sensors provided a very reproducible response and their abilities for electrochemical detection of organophilic pollutants reached the trace levels.

Table 2 summarizes the behavior of several CLME toward fungicide determination, mainly propineb, carbendazim, and chlorpyrifos [21,42-45]. A broad range of CLME configuration was observed, ranging from the application of raw nanoclays to advanced nanoclay composites with mainly carbon nanotubes and metal NPs. Moreover, the analysis of the results was even more complicated as several detection techniques were applied to characterize the electrochemical sensors. In general, a wide linear range was observed for all sensors; however, it was different for each specific configuration, as expected. As well, the limit of detection (LOD) was quite small for all of them, specifically for the detection of chlorpyrifos. A special case was the CLME with $\mathrm{Cu}^{+2}$-montmorillonite for propineb detection. It presented the highest linear range observed for all the electrodes $(5.0-30 \mu \mathrm{M})$. However, its LOD was the highest observed, and ca. 100-1000 times higher than those previously reported for classical electrochemical sensors.

Table 2. Performances of several chemically modified electrodes toward fungicide determination.

\begin{tabular}{|c|c|c|c|c|c|c|}
\hline Clay & Modifier & Analyte & $\begin{array}{l}\text { Detection } \\
\text { Technique }\end{array}$ & $\begin{array}{l}\text { Analytical Range } \\
\qquad(\mu \mathrm{M})\end{array}$ & $\begin{array}{l}\text { LOD } \\
(\mu \mathrm{M})\end{array}$ & Ref. \\
\hline Montmorillonite & $\mathrm{Cu}^{2+}$ & Propineb & SWV & $5.0-30$ & 1 & [42] \\
\hline Montmorillonite & Octyltriethoxisilane & & $\mathrm{CV}$ & $1-7$ & 0.03 & [44] \\
\hline Montmorillonite & - & Carbendazim & DPV & - & 0.96 & [45] \\
\hline Montmorillonite & Heteropolyacid & & SWV & $0.052-2.615$ & 0.052 & [21] \\
\hline CLDH & AChE & Chlorpyrifos & DPV & $1.43 \times 10^{-4}-0.43$ & $1.43 \times 10^{-4}$ & [43] \\
\hline
\end{tabular}

SWV: square wave voltammetry; DPV: differential pulse voltammetry; CV: cyclic voltammetry; CLDH: Cu-Mg-Al calcined-layered double hydroxide; AChE: acetylcholinesterase. 
The same situation was observed for the determination of carbendazim by Namontmorillonite [45], showing a LOD considerably higher than the rest of the nanoclay sensors shown in Table 2. This drawback can be overcome with the montmorillonite organofunctionalization (Octyltriethoxisilane-Mt/CPE and Heteropolyacid Mt/GCE), which produces a decrease in the LOD in one order of magnitude [21,44].

The best performance was observed for the detection of chlorpyrifos. In this case, double-layered hydroxides loaded with acetylcholinesterase (AChE) were employed and this CLME exhibited a good response for the chlorpyrifos' detection in the different configurations probed [43].

Herbicide detection has also been studied with CLME (Table 3) [20,21,38-40,45-47]. Diverse electrode configuration has been tested, with paraquat being the most common analyte detected. In general, the best performance was obtained when organonano-nanoclays were used. An example is the use of DDA-Saponite (SaDDA/GCE) vs. Na-Saponite (SaNa/GCE) for mesotrione detection [20] or organomontmorillonite film vs. sodium montmorillonite film/GCE for phenyl urea herbicide detection [21,45]. A particular case is the use of CLME for paraquat detection, where the use of raw smectites in the CLME resulted in good LOD and linear range $[38,46,47]$.

Table 3. Performances of several chemically modified electrodes toward herbicide determination.

\begin{tabular}{|c|c|c|c|c|c|c|}
\hline Clay & Modifier & Analyte & $\begin{array}{l}\text { Detection } \\
\text { Technique }\end{array}$ & $\begin{array}{c}\text { Analytical } \\
\text { Range }(\mu \mathrm{M})\end{array}$ & $\begin{array}{l}\text { LOD } \\
(\mu \mathrm{M})\end{array}$ & Ref. \\
\hline Cameroonian smectite & - & \multirow{3}{*}{ Mesotrione } & SWV & 5-19 & - & [20] \\
\hline Cameroonian smectite & Cetyltrimethyl ammonium & & SWV & $1.25-9.80$ & - & [20] \\
\hline Cameroonian smectite & DDA & & SWV & $0.25-2.24$ & 0.26 & [20] \\
\hline montmorillonite & Triethoxyoctylsilane & Glyphosate & SWV & $10-100$ & 0.98 & [39] \\
\hline NiAl-LDH & - & \multirow{3}{*}{$\begin{array}{l}\text { phenyl urea } \\
\text { herbicides }\end{array}$} & $\mathrm{CV}$ & $0.02-0.18$ & 0.001 & [40] \\
\hline montmorillonite film & - & & $\mathrm{CV}$ & $0.206-61.8$ & 0.206 & [45] \\
\hline montmorillonite & Organo functionalized & & SWV & $5 \times 10^{-3}-1.45$ & $5 \times 10^{-3}$ & [21] \\
\hline montmorillonite & $\mathrm{K}^{+}$ & \multirow{3}{*}{ Paraquat } & $\mathrm{CV}$ & $0.03-0.4$ & $0.14 \times 10^{-3}$ & [38] \\
\hline Smectite film & - & & SWV & $1.6-2.8$ & $3.8 \times 10^{-3}$ & [46] \\
\hline clay composite film & $\beta$-cyclodextrin & & DPV & $0.099-1.99$ & $2.8 \times 10^{-3}$ & [47] \\
\hline
\end{tabular}

SWV: square wave voltammetry; DPV: differential pulse voltammetry; CV: cyclic voltammetry; NiAl-LDH: layered double hydroxide; DDA: didodecyldimethyl ammonium.

The LOD of glyphosate by electrochemical electrodes based in carbon is higher than those based in metallic particle but they provided a wider concentration of range of detection [39].

As stated in the introduction, biosensors are special electrochemical sensors, defined as an analytical device in which a biological response is converted into a signal that can be quantified and processed [48]. Enzymatic biosensors based on CLME can be used for the determination of pesticides through their inhibitory action on enzyme activity. In the last decade, the main studies have been centered in the determination of glyphosate and chlorpyriphos (see Table 4) [49-51].

Table 4. Behavior of several enzymatic biosensors toward herbicide determination.

\begin{tabular}{cccccc}
\hline \multirow{2}{*}{ Clay } & Enzyme & Analyte & $\begin{array}{c}\text { Detection } \\
\text { Technique }\end{array}$ & $\begin{array}{c}\text { Analytical } \\
\text { Range (mg/L) }\end{array}$ & $\begin{array}{c}\text { LOD } \\
(\mathbf{m g} / \mathrm{L})\end{array}$ \\
\hline Nanoclay & Atemoya peroxidase & Glyphosate & SWV & $100-4550$ & 30 \\
\hline CH-Mt & AChE & & CV & $0.5-1000$ & 0.448 \\
Kaol & AChE & & EIS & $0.5-200$ & {$[49]$} \\
Mt & AChE & Chlorpyrifos & EIS & $0.5-100$ & 0.28 \\
Bent & AChE & & EIS & $2-200$ & 0.48 \\
Sep & AChE & & EIS & $2-200$ & 0.65 \\
\hline
\end{tabular}

AChE: acetylcholinesterase; Kaol: kaolinite; Mt: montmorillonite; Bent: bentonite; Sep: sepiolite; CH-Mt = chitosan-montmorillonite; SWV: square wave voltammetry; CV: cyclic voltammetry; EIS: electrochemical impedance spectroscopy. 
For example, a biosensor based on atemoya peroxidase immobilized into a modified nanoclay (montmorillonite containing 0.5-5 wt.\% aminopropyltriethoxysilane and 15-35 wt.\% octadecylamine) was developed [49]. The linear range of this biosensor for the detection of glyphosate was satisfactory. It was constructed using graphite powder, multiwalled carbon nanotubes, peroxidase immobilized on nanoclay, and mineral oil. The best performance was obtained using a $0.1 \mathrm{~mol} \cdot \mathrm{L}^{-1}$ phosphate buffer solution ( $\mathrm{pH}$ 7.0), $1.9 \times 10^{-4} \mathrm{~mol} \cdot \mathrm{L}^{-1}$ hydrogen peroxide, a frequency of $30 \mathrm{~Hz}$, a pulse amplitude of $50 \mathrm{mV}$, and a scan increment of $4 \mathrm{mV}$. This biosensor remained stable for a period of 8 weeks.

For the detection of chlorpyriphos, several nanoclays functionalized with chitosan [50] or metallic NPs [52] were employed for the fabrication of enzymatic biosensors via immobilization of acetylcholinesterase (AChE) [50,51].

The hybridization of nanoclays and Au NPs provided remarkable composite materials with high electrochemical conductivity, high surface-to-volume ratio, high chemical reactivity, and chemisorption capacity of various types of molecules [53]. Phongphut et al. [51] found that Montmorillonite with Au NPs (Mt/Au NPs) was the best support for AChE loading, showing residual activities due to its high specific surface area and weak electrostatic interaction with the immobilized enzyme (Figure 2). However, when kaolinite was used as supported material for the Au NPs (Kaol/AuNPs), a lowest detection limit resulted, presumably due to the strong hydrophobic surface that helped to concentrate the nonpolar pesticide to the vicinity of the immobilized enzyme. Unfortunately, the highest electrostatic repulsion between the Kaol/AuNPs and AChE and the dehydrated kaolinite surface resulted in the lowest storage stability of the AChE pesticide sensors. Overall, $\mathrm{Mt} / \mathrm{AuNPs}$ showed the highest potential as the AChE carrier and the modified electrode material for chlorpyrifos' determination.

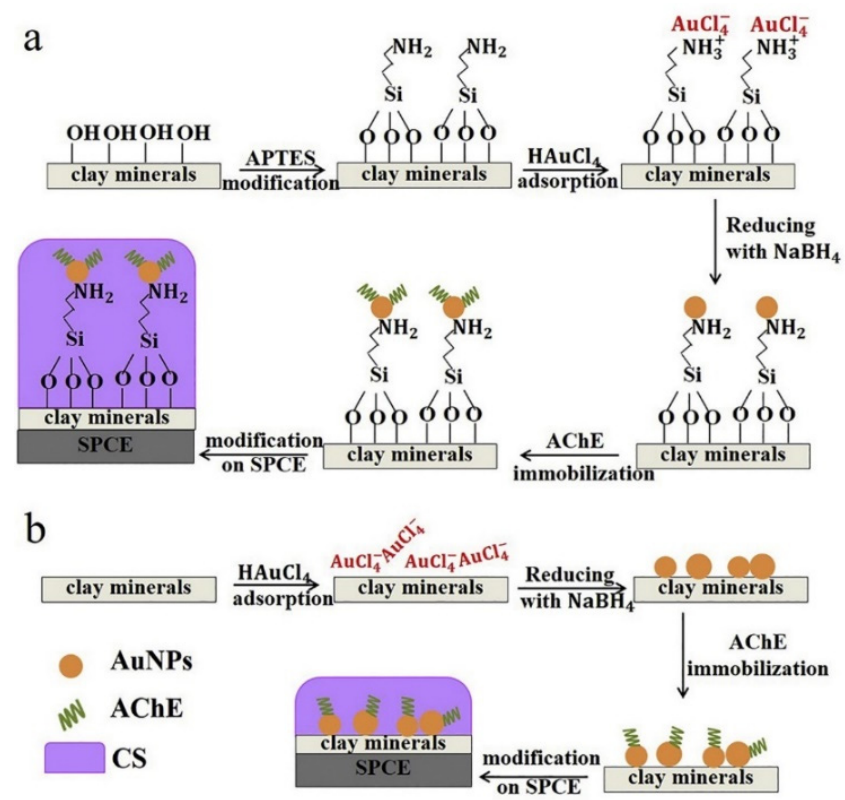

Figure 2. Schematic representation of clay/AuNPs synthesis, AChE immobilization, and SPCE modification with (a) successful APTES modification and (b) unsuccessful APTES modification. Reprinted with permission from ref. [51]. Copyright 2020 Elsevier.

\section{Nanoclay-Based Sensors for Biomedical Applications}

The development of diverse strategies for detection of bioanalytes shows great importance in biomedicine, clinical diagnosis, and treatment. Determination of small metabolic molecules, mainly glucose, hydrogen peroxide $\left(\mathrm{H}_{2} \mathrm{O}_{2}\right)$, and dopamine, in biological fluids at low concentrations is fundamental for the early diagnosis of several diseases $[54,55]$. Two main sensors' groups can be found related to this topic. The first one is classical electrochemical electrodes modified by the inclusion of nanoclays. In this group, special 
recognition to nanoclay-based biosensors will be given in this section. The second one corresponds to optical sensors based on the adsorption of a fluorophore molecule in nanoclays. In the following paragraphs, a description of the recent nanoclay-based sensors for the detection of several bioanalytes is presented, divided in terms of the bioanalyte detected and type of nanoclay sensor (electrochemical, biosensor, and optical).

\subsection{Nanoclay-Based Electrochemical Sensors}

\subsubsection{Glucose Determination}

Unbalanced glucose levels in blood are used as an evidence of several chronic metabolic disorders, diabetes being the most common disease [56]. Elevated glucose levels in blood are also associated with other serious endocrine disorders, certain infections, and nervous, ocular, and cardiac diseases. Therefore, an inexpensive, sensitive, and fast method for monitoring glucose is needed at physiological concentrations of approximately $3-8 \mathrm{mM}$. Enzymatic glucose biosensors based on nanoclays have recently acquired attention due to their good performance in terms of detection limit, stability, sensibility, and selectivity for in vitro glucose determination from human biological fluids [57-59]. Several authors have applied raw and functionalized clays in biosensors' preparation for glucose detection, as stated in Table 5 [60-72].

Table 5. Electrochemical nanoclay sensors for glucose detection.

\begin{tabular}{|c|c|c|c|c|c|c|c|}
\hline Enzyme & Clay & $\begin{array}{l}\text { Functional } \\
\text { Molecule }\end{array}$ & Electrode & $\begin{array}{c}\text { Analytical } \\
\text { Ranges (mM) }\end{array}$ & $\operatorname{LOD}(\mu \mathrm{M})$ & $\begin{array}{c}\text { Response } \\
\text { Time (s) }\end{array}$ & Ref. \\
\hline GOx & Mt & $\mathrm{M} / \mathrm{DM}$ & Carbon & $0.05-1.0$ & 38 & 7 & [60] \\
\hline GOx & Mt & $\begin{array}{l}\text { PAMAM } \\
\text { dendrimer }\end{array}$ & Carbon & $0.01-16$ & 4 & $<3$ & [61] \\
\hline PyOx & Mt & PVA/PAMAM & Carbon & $0.005-0.25$ & 0.7 & - & [62] \\
\hline PyOx & Mt & Calixarene & Carbon & - & 0.5 & 20 & [63] \\
\hline G. oxydans & Mt & trimethylamine & GCE & $0.1-5.0$ & - & - & [64] \\
\hline GOx & $\mathrm{Mt}$ & Gly, Lys, Glu & Carbon & $0.1-1.0$ & - & - & [65] \\
\hline $\mathrm{PyOx}$ & Dellite & CTAB & Carbon & $0.01-0.5$ & 0.081 & - & [66] \\
\hline GOx & Pal & PoPD & Pt disk & $0.05-3.7$ & 0.0624 & 6 & [67] \\
\hline $\mathrm{PyOx}$ & Mt & PGA & Carbon & $0.01-0.5$ & - & - & [68] \\
\hline PyOx & $\mathrm{Mt}$ & 4-ATP & Carbon & $0.01-0.5$ & - & - & [69] \\
\hline GOx & Lap & VBT/VBA & Carbon & - & - & - & [70] \\
\hline GOx & Lap & PMMA/poly(BIPE)/ & Graphite & - & - & - & [71] \\
\hline GOx & Mt & $\mathrm{PAN} / \mathrm{DDAC} / \mathrm{MB}$ & - & $\begin{array}{c}0.01-2.45 \\
2.45-15\end{array}$ & 2 & - & [72] \\
\hline
\end{tabular}

GOx: glucose oxidase; PyOx: pyranose oxidase; Mt: montmorillonite; Pal: palygorskite; Lap: laponite; M: methylamine; DM: dimethylamine; PAMAM: Poly(amidoamine); PVA: poly(vinyl) alcohol; Gly: glycine; Lys: lysine; Glu: glutamic acid; CTAB: cetyltrimethylammonium bromide; PoPD: Poly (o-phenyledediamine); PGA: polyglycolide; 4-ATP: 4-aminothiophenol; VBT: vinylbenzyl thymine; VBA: vinylbenzyl triethylammonium chloride; PMMA: polymethylmethacrylate; PAN: polyacrylonitrile; DDAX: dioctadecyl dimethyl ammonium chloride; MB: methylene blue.

A schematic representation of an enzyme biosensor based on electrode with nanoclay for glucose determination is shown in Figure 3 [23]. In these biosensors, glucose is oxidized and gluconic acid is generated. The electrical signal is produced by a mediator that produces a redox reaction with the adenine dinucleotide (FAD), a component of glucose oxidase (GOx), the most common enzyme used in enzyme electrodes [23]. The reactions are depicted as follows:

$$
\begin{gathered}
\mathrm{GO}_{\mathrm{x}}(\mathrm{FAD})+\text { Glucose } \rightarrow \mathrm{GO}_{\mathrm{x}}\left(\mathrm{FADH}_{2}\right)+\text { Gluconic acid } \\
\mathrm{GO}_{\mathrm{x}}\left(\mathrm{FADH}_{2}\right)+\mathrm{Med}_{\mathrm{ox}} \rightarrow \mathrm{GO}_{\mathrm{x}}(\mathrm{FAD})+\mathrm{Med}_{\mathrm{red}}
\end{gathered}
$$

Seleci et al. [60] described a simple and accurate electrochemical method using methyland dimethylamine-exchanged montmorillonite as an immobilization matrix. GOx was chosen as a model enzyme in the presence of bovine serum albumin (BSA) and glutaralde- 
hyde, and they were immobilized on the clay-modified glassy carbon electrodes (GCE). In order to optimize the biosensor, the influence of the working $\mathrm{pH}$, enzyme amount, and reproducibility of biosensor fabrication was characterized in detail. The optimized biosensor showed a very good linearity between $0.05 \mathrm{mM}$ and $1.0 \mathrm{mM}$, a $7 \mathrm{~s}$ response time, and a LOD to glucose of $0.038 \mathrm{mM}$. Kinetic parameters and stabilities were also determined.

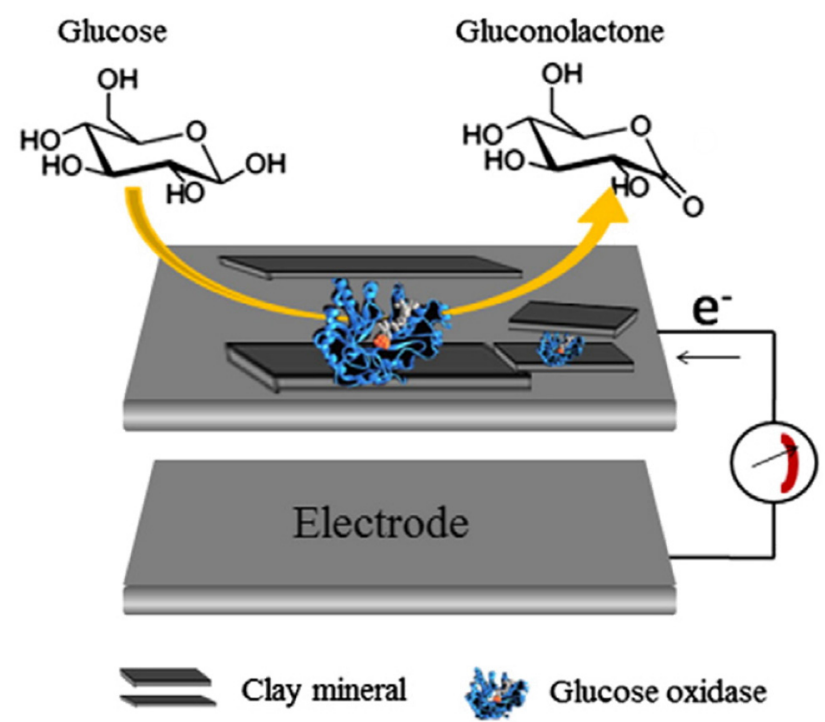

Figure 3. A schematic drawing of enzyme biosensor based on electrode with nanoclay hybrids. Reprinted with permission from ref. [23]. Copyright 2015 Elsevier.

Following the same approach, Han et al. [61] used dendritic macromolecules, in particular poly-amydoamine (PAMAM), to modify the electrode surface. PAMAM is able to prevent NPs' aggregation and to increase the concentration of hydrophobic molecules at the surface. To improve the electron-transfer efficiency of the enzyme with the inorganic material, platinum NPs were encapsulated in the PAMAM polymer (Pt-DENs). Positively charged Pt-DENs were subsequently hybridized with negatively charged montmorillonite particles through electrostatic interaction. GOx was immobilized in this hybrid and used to modify a GCE to obtain an enzymatic glucose biosensor. The nanohybrid material and the sensor were characterized by cyclic voltammetry and amperometry. The biosensor had a response time below $3 \mathrm{~s}$ and a LOD as low as $4 \mu \mathrm{M}$.

Demir et al. extensively worked on the development of clay-based biosensors for glucose determination. First, they used glycine- (Gly), lysine- (Lys), and glutamic acid(Glu) modified clay mineral matrices in the biosensors [65]. GOx was selected as the model enzyme. After immobilizing the enzyme with amino acid-modified montmorillonite onto a GCE, working conditions like $\mathrm{pH}$ and modifier type were optimized. The linear range of optimum sensor design was 0.1-1.0 mM. Later, they proposed an innovative Gluconobacter oxydans cells' immobilization strategy on trimethylamine-functionalized montmorillonite [64]. The usage of microbial cells provided several advantages. Enzymes inside cells do not need to be purified and can be regenerated in natural conditions since cofactors and coenzymes are already in the cell. Since Gluconobacter oxydans (G. oxydans) is an obligate aerobe, it has a fast and high oxidation efficiency. Hence, the G. oxydans genus is regarded as an ideal component for the fabrication of whole-cell biosensing systems. Measurements concerning analytical characteristics, operational stability, repeatability, and substrate specificity, depending on the carbon source, were investigated in a flow injection analysis (FIA) system. Linear ranges were found between 0.15 and $5.0 \mathrm{mM}$ for the batch mode and 0.1 and $5.0 \mathrm{mM}$ for the FIA system, respectively.

By changing the inorganic material, Dellite (a commercial nanoclay derived from bentonite) instead of montmorillonite, and by using quaternary ammonium cations as organic, Maiga et al. [66] presented a novel support material for enzyme immobilization 
based on cetyltrimethylammonium bromide- (CTAB) modified Dellite (CTAB-Del). In this case, the use of inorganic matrix was proposed as an alternative to organic polymers for immobilization of biomolecules. Then, pyranose oxidase (PyOx) was immobilized onto the GCE, via glutaraldehyde cross-linking, and Chronoamperometric measurements were carried out using three electrodes' configurations, at a constant potential of $-0.7 \mathrm{~V}$ in working buffer, under stirring, with successive addition of glucose. The biosensor presented a good linearity, in a range from 0.01 to $0.50 \mathrm{mM}$, and the LOD for glucose was calculated to be $0.081 \mu \mathrm{M}$. Additionally, its in vitro antimicrobial activity was also tested by means of the disc diffusion susceptibility test, selecting three different Gram-positive and five different Gram-negative bacteria. The obtained results showed a moderate antibacterial activity of CTAB-Del against Gram-positive bacteria.

Polymer molecules have been extensively used to immobilize biomolecules in biosensors, as was introduced above. In this sense, Luo et al. [67] synthesized a novel biosensor for glucose detection based on Palygorskite-poly(o-phenylenediamine) nanocomposite. Palygorskite is a clay mineral characterized by a fibrous morphology and it is presented here as a promising material for enzyme immobilization. The combination of palygorskite with the conducting polymer poly(o-phenylenediamine) was exploited as a matrix for the immobilization of GOx using glutaraldehyde as cross-linker. This novel glucose biosensor presents a good detection answer under amperometric measurements for the detection of glucose, by holding the potential at the electrode at $0.6 \mathrm{~V}$ for the oxidation of $\mathrm{H}_{2} \mathrm{O}_{2}$ generated in the enzymatic reaction. The proposed biosensor exhibited a wide linear range, a low detection limit, a good reproducibility, and accepted stability.

Under a similar strategy, Unal et al. [68] prepared a polymer/clay nanocomposite based on natural silicate montmorillonite (Mt) and a biodegradable polymer polyglycolide (PGA). Then, the resulting matrix was used as a fixation matrix for pyranose oxidase (PyOx), which was selected as a model enzyme. The bioactive layer was fabricated by the immobilization of PyOx on GCE by means of PGA-Mt and BSA. This biosensor revealed a good linear range from 0.01 to $0.5 \mathrm{mM}$ glucose with a LOD of $1.2 \mu \mathrm{M}$. Most recently, Yilmaz et al. [69] explored an organic-inorganic hybrid material formed by 4-aminothiophenolintercalated montmorillonite (4ATP-Mt) as an immobilization layer for the pyranose oxidase (PyOx) enzyme on a GCE. The 4-aminothiphenol or p-mercaptoaniline is an organic compound that has been previously used to form self-assembled layers on gold electrodes. The 4ATP-Mt/PyOx biosensor exhibited a wide linear concentration range, between 0.01 and $0.5 \mathrm{nM}(\mathrm{LOD}: 1.0 \mu \mathrm{M})$, for glucose.

Hydrogel polymer-nanoclays have also been explored as a biosensor platform. An accurate quantification of glucose with a quick and easy method has driven the search for new procedures of analysis. In this regard, glucose biosensors have been significantly developed in recent years, as exposed previously. However, scientific advances have not been accompanied by corresponding technological improvements and their application in health and general industry areas is very limited. In particular, Paz Zanini et al. [70] proposed the enzyme immobilization using hydrogel films made of the synthetic nanoclay laponite as a very suitable method that satisfies most of the following requirements: specificity, portability, quickness, and comparative low cost. Here, laponite has been extensively used in combination with polycations for the formation of hydrogel films on a suitable electrode and entrapping an active enzyme for bioelectrochemical sensing. As mentioned above, the incorporation of polycation molecules into the hydrogel film improves both the mechanical stability and the electrical conductivity of the interface, increasing the low conductivity of the anionic clay. Moreover, this procedure helps retain the active enzyme in the hydrogel film. In this work, a series of Thymine-based polymers inspired by DNA made of vinylbenzyl thymine (VBT) and vinylbenzyl triethylammonium chloride (VBA) were used in combination with laponite for the immobilization of GOx onto GCE. The enzymatic reaction was conducted using the natural mediator of the enzyme $\left(\mathrm{O}_{2}\right)$ and also an artificial mediator, ferrocenemethanol ( $\mathrm{FcMe})$, allowing the electrochemical detection of glucose at two ranges of very different working potentials. They showed that 
the optimized hydrogel biosensor presented almost two orders of magnitude larger than other laponite-immobilized GOx bioelectrodes reported elsewhere [73-75].

Emre et al. [71] proposed a polymer-laponite nanocomposite made of polymethylmethacrylate (PMMA) as biosensor platform for glucose sensing. Layered silicate nanocomposites were prepared by in situ suspension polymerization by grafting PMMA with laponite using a suitable grafting agent. A conducting polymer (poly(4-(2,3-dihydrothieno [3,4-b][1,4]dioxin-5-yl)-7-(2,3-dihydrothieno[3,4-b][1,4]dioxin-7-yl)-2-benzyl-1H-benzo[d]i midazole) (poly(BIPE))) and a PMMA clay nanocomposite with 2-(methacryloyloxy) ethyltrimethylammonium chloride (MTMA) modifier was examined as a platform for biomolecule deposition. GOx was chosen as the model enzyme to prepare a scaffold for glucose sensing. Three different sensing strategies were analyzed and their biosensor performances were discussed. Among the different biosensors examined, the one formed with PMMA-clay nanocomposite and poly(BIPE) exhibited the best performance for glucose sensing. It served as a proper immobilization platform for enzyme molecules, achieving superior biosensor performance than the other combination tested. Moreover, a more proper enzyme deposition and proficient surface chemistry was achieved. By this way, electrochemical signal for glucose detection was amplified and an improved biosensor was achieved.

Electrospinning was proposed as an innovative technique for generating nanofiber assemblies [72]. The engineering of the nanofiber provides enhanced surface area platforms for immobilization of biomolecules and can improve the transduction process, leading to high biosensor efficiency. Apetrei et al. [72] proposed the use of a promising composite nanofiber material incorporating montmorillonite $\mathrm{K} 10$ as nanoclay and a common electrospinning polymer, polyacrylonitrile (PAN), as biosensing matrices for amperometric detection of glucose by cross-linking of GOx. Mt acts as a suitable immobilization platform for biocatalysts and allows functionalization through intercalation with the organic molecules, dioctadecyl dimethyl ammonium chloride and methylene blue. The former is able to change the chemical properties of the clay from hydrophilic to organophilic, whereas the latter is a known redox mediator. As result, both PAN/Montmorillonite and PAN/functionalized montmorillonite improved the performance of the constructed biosensors, increasing the linearity, which extended up to $15 \times 10^{-3} \mathrm{M}$ within two linear ranges $\left(1.0 \times 10^{-5}-2.45 \times 10^{-3} \mathrm{M}\right.$ and $\left.2.45 \times 10^{-3}-15 \times 10^{-3} \mathrm{M}\right)$, and improving the sensitivity. The LOD was also lowered from 4.2 to $2.4 \mu \mathrm{M}$ and the operational stability was enhanced up to $85 \%$ as result of incorporation of the ammonium ions.

Under a similar context, Unal et al. [62] suggested a good alternative to immobilize biomolecules in electrospun nanofibers. Electrospun nanocomposite nanofibers are prepared by using clay and various types of polymers. In this work, montmorillonite was modified with PAMAM G2 dendrimers, which provided free amine groups that were used for the covalent immobilization of pyranose oxidase enzyme in order to prepare stabile enzyme biosensors. Then, PVA/PAMAM-Mt electrospun nanofibers were formed on the surface of GCE using PVA as the supporting polymer. The linear response for glucose was from $0.005 \mathrm{mM}$ to $0.25 \mathrm{mM}$ using PVA/Mt/PyOx and PVA/PAMAM-Mt/PyOx biosensors. LOD was $0.7 \mathrm{mM}$ glucose with PVA/PAMAM-Mt/PyOx biosensor.

Sonmez et al. [63] reported the synthesis, characterization, and application of calixarene (Calix)-modified montmorillonite as a platform for biomolecule immobilization and biosensing. This modification enhanced the biomolecule immobilization capability of Mt. For the biosensor construction, Calix- $\mathrm{NH}_{2}$-modified Mt (Calix- $\left.\mathrm{NH}_{2} / \mathrm{Mt}\right), \mathrm{BSA}$, glutaraldehyde (GA), and pyranose oxidase were immobilized on the surface of GCE. After optimization of the enzyme amount and $\mathrm{pH}$, analytical characteristics were investigated in detail.

LDHs, hydrotalcite-like compounds, have been widely used in the last two decades as electrochemical biosensing platform and biomarker determination for early disease diagnoses. An extensive descriptive analysis of recent development of LDHs sensor in in vitro determination of small biomarkers can be found in several reviews [76-78]. 
A smart example presented by Gualandi et al. [79] consisted of the development of a new composite material with electrochemical features combining LDHs with graphene and/or carbon nanotubes. Many LDHs' applications are restricted because of their low electrical conductivity decay during device operation due to the volume change associated with a variation of the redox state of the material. These weak points can be overcome by combining LDHs with carbon nanotubes and graphene. The aim of the work was the development of an electrosynthesis protocol that allows the preparation of nanostructure films by the deposition of a Ni/Al-based LDHs on carbon nanomaterial film to produce a new electrochemical interface that takes advantage of the unique properties of both materials. The materials were tested for glucose electro-oxidation, which was exploited for the fabrication of a sensor with high sensitivity and low $\mathrm{LOD}(0.6 \mu \mathrm{M}$ for the best device) of glucose. In a similar way, Wang et al. [80] described a GC electrode modified with a graphene-doped film of LDHs for selectively sensing of dopamine.

\subsection{2. $\mathrm{H}_{2} \mathrm{O}_{2}$ Detection}

$\mathrm{H}_{2} \mathrm{O}_{2}$ plays an important role in various applications such as medical diagnostics, clinical research, and industrial sectors. For example, it is involved in metabolic activities and it is a crucial biomarker in monitoring various diseases and disorders including diabetes and cancer [81]. Further, $\mathrm{H}_{2} \mathrm{O}_{2}$ is used for sterilizing various medical equipment, and residual $\mathrm{H}_{2} \mathrm{O}_{2}$ levels need to be monitored to ensure that the equipment is safe to use [82]. Therefore, the sensitive detection of $\mathrm{H}_{2} \mathrm{O}_{2}$ is an important task. There are a variety of methods to detect and quantify $\mathrm{H}_{2} \mathrm{O}_{2}$ that have been in use for many years, including titration, chromatography, light detection, and electrochemical sensors [83]. Nanoclays can be applied in the direct determination of $\mathrm{H}_{2} \mathrm{O}_{2}$ using two different mechanisms: either with an electrochemical sensing platform or by a colorimetric method. The first one will be exposed in this section, whereas the optical sensors will be exposed later on.

Nanoclays' minerals are used in electrochemical devices for $\mathrm{H}_{2} \mathrm{O}_{2}$ detection due to their ability to stabilize metal NPs and metal oxide NPs. In fact, $\mathrm{Cu}, \mathrm{CuO}, \mathrm{Cu}_{2} \mathrm{O}, \mathrm{Ag}, \mathrm{Au}$, and Pt NPs have been incorporated in anionic and cationic nanoclays to develop CLME with an effective response to $\mathrm{H}_{2} \mathrm{O}_{2}$ detection [84-93]. A list of several devices found in the last decade in the literature concerning CLME for detecting $\mathrm{H}_{2} \mathrm{O}_{2}$ can be found in Table 6 .

The smallest detection limit was obtained in hallosyte-based CLME, that is, at least 1 order of magnitude smaller than in the rest of the sensors studied. Moreover, on these sensors, excellent sensing behavior was detected, as a wide, linear range detection limit was observed [84-87]. LDH samples exhibited, by far, the highest sensitivity, probably due to the 2D hierarchical porous structure of the LDH-carboxymethyl chitosan (CMC) support, associated with sufficient active sites that provide a biocompatible micro-environment for enzyme adsorption and a pathway for $\mathrm{H}_{2} \mathrm{O}_{2}$ diffusion [91,92].

Many natural clays have iron incorporated in their structures and this element can affect the CLME response in the $\mathrm{H}_{2} \mathrm{O}_{2}$ detection, as studied by Charradi et al. [93]. Their results confirmed that nanoclays (both natural and synthetic) containing Fe(III), specifically $\mathrm{Mt}$, can mediate electron transfer via the contained electrochemically active iron species in their octahedral lattice. In fact, they also studied a saponite with Fe ions in the tetrahedral sheet that did not show any electroactivity. They concluded that iron-rich CLME offer the possibility of developing very sensitive analytical methods for $\mathrm{H}_{2} \mathrm{O}_{2}$. Moreover, in these cases, the adsorption of an organic dye (methyl viologen, $\mathrm{MV}^{2+}$ ) or a biomolecule as hemoglobin $(\mathrm{Hb})$ in the clay layers considerably improved the sensor performance, as shown in Table 6 [93]. 
Table 6. Nanoclay-based electrochemical sensors for $\mathrm{H}_{2} \mathrm{O}_{2}$ detection.

\begin{tabular}{|c|c|c|c|c|c|c|}
\hline Nanoclay & Functional Molecule & Electrode & $\begin{array}{l}\text { LOD } \\
(\mu \mathrm{M})\end{array}$ & $\begin{array}{l}\text { Analytical Range } \\
\text { (mM) }\end{array}$ & $\begin{array}{c}\text { Sensitivity } \\
\left(\mu \mathrm{A} \cdot \mathrm{mM}^{-1} \cdot \mathrm{cm}^{-2}\right)\end{array}$ & Ref. \\
\hline Hallosyte & AgNP-PANI & GCE & 0.3 & $5 \times 10^{-4}$ to 4.7 & 74.8 & [84] \\
\hline Hallosyte & $\mathrm{Ag}-\mathrm{MnO}_{2}$ & GCE & 0.7 & $2 \times 10^{-3}$ to 4.71 & 11.9 & [85] \\
\hline Hallosyte & AuNP & GCE & $1 \cdot 10^{-3}$ & $5 \times 10^{-3}$ to 0.255 & 70 & [86] \\
\hline Hallosyte & & GCE & 0.226 & $4 \times 10^{-3}$ to 1.064 & 0.98 & [87] \\
\hline Bentonite & $\mathrm{CuONP}$ & GCE & 4.93 & $5 \times 10^{-3}$ to 10 & 60 & [88] \\
\hline Bentonite & Ag NPs & GCE & 9.1 & $1 \times 10^{-3}$ to 5.0 & 4.7 & [89] \\
\hline Sepiolite & $\mathrm{Cu} 2 \mathrm{O} \mathrm{NP}$ & GCE & 10.2 & $0.02-2.36$ & 665 & [90] \\
\hline LDH & CoAl NPs & GCE & 10 & - & 118.0 & [91] \\
\hline ZnAl-LDH & $\begin{array}{l}\text { carboxymethyl } \\
\text { chitosan (CMC) }\end{array}$ & GCE & 12.4 & $0.02-6.0$ & 220.4 & [92] \\
\hline Nontronite & - & GCE & 109 & $0.63-2.45$ & 0.23 & [93] \\
\hline Nontronite & $\begin{array}{l}\text { methyl viologen } \\
\left(\mathrm{MV}^{+2}\right)\end{array}$ & GCE & 10 & $\begin{array}{l}0.01-5 \\
12-40\end{array}$ & $\begin{array}{l}9.4 \\
54\end{array}$ & [93] \\
\hline Notronite & $\begin{array}{l}\text { Bovine hemoglobin } \\
\qquad(\mathrm{Hb})\end{array}$ & GCE & - & $2-15$ & 132 & [93] \\
\hline $\begin{array}{l}\text { Montmorillonite synthetic } \\
\text { (Fe III octahedral) }\end{array}$ & 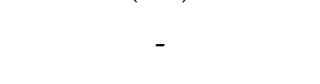 & GCE & 246 & $0.25-1.60$ & 0.10 & [93] \\
\hline $\begin{array}{l}\text { Montmorillonite synthetic } \\
\text { (Fe III octahedral) }\end{array}$ & $\begin{array}{c}\text { methyl viologen } \\
\left(\mathrm{MV}^{+2}\right)\end{array}$ & GCE & 10 & $\begin{array}{c}0.01-4 \\
5-40\end{array}$ & $\begin{array}{c}53 \\
132\end{array}$ & [93] \\
\hline $\begin{array}{l}\text { Montmorillonite synthetic } \\
\text { (Fe III octahedral) }\end{array}$ & $\begin{array}{l}\text { Bovine hemoglobin } \\
\qquad(\mathrm{Hb})\end{array}$ & GCE & - & $2-12$ & 74 & [93] \\
\hline $\begin{array}{l}\text { Montmorillonite synthetic- } \\
\text { non-iron impurities) }\end{array}$ & $\begin{array}{l}\text { Bovine hemoglobin } \\
\qquad(\mathrm{Hb})\end{array}$ & GCE & - & $4-18$ & 0.043 & [93] \\
\hline
\end{tabular}

PANI: polyaniline; GCE: glassy carbon electrode.

\subsubsection{Other Organic Biomedical Compounds' Detection}

The rapid and sensitive detection of salicylic acid has also great importance in organic synthesis and medicine. Electrochemistry presents some problems for detection of salicylic acid with ordinary electrodes ( $\mathrm{Pt}, \mathrm{Au}$, carbon paste, and graphite). Gualandi et al. [94] presented a Pt electrode modified with a Co/Al-based hydrotalcite for salicylic acid determination by both differential pulse voltammetry and chronoamperometry. The linearity analytical ranges and the LOD values were measured to be $10^{-5}$ to $5 \times 10^{-4}$ and $5 \times 10^{-7}$ to $10^{-4} \mathrm{M}$, as well as $6 \times 10^{-6}$ and $2 \times 10^{-7} \mathrm{M}$, for both techniques, respectively.

Niclosamide has been widely used as anthelmintic medicine. However, its prolonged use produces extensive residues in water that can involve toxicity, and a simple detection system for niclosamide is highly desirable. Zhao et al. [17] reported the preparation of carbon NPs-decorated HNTs' nanocomposite, which was successfully applied to modify a carbon electrode for niclosamide determination. This sensor exhibited excellent performance with a relatively low LOD of $3.28 \mathrm{nM}$ in the $0.01-1 \mu \mathrm{M}$ linear range. Additionally, cefotaxime is a broad spectrum antibiotic widely used to treat bacterial respiratory and urinary infections, because of its activity against Gram-positive and Gram-negative bacteria. Dehdashtian et al. [95] described a sensitive and selective sensor based on carbon paste electrode modified by montmorillonite/graphene oxide composite developed for the electrochemical determination of Cefotaxime. This modified electrode exhibited a linear response over two different linear concentration ranges, from 0.5 to $40 \mathrm{nM}$ and 40 to $2400 \mathrm{nM}$, with a LOD of $0.1 \mathrm{nM}$.

Finally, Joshi et al. [96] also developed electrodes based on laponite and montmorillonite clays and imidazolium chloride-based ionic liquids. These electrodes were used for detection of diverse bioanalytes, namely, ascorbic, oxalic, and citric acid, as well as urea, glucose, or cholesterol.

Table 7 summarizes the behavior of several CLME toward organic compounds' detection. 
Table 7. Nanoclay-based electrochemical sensors for organic compounds' detection.

\begin{tabular}{|c|c|c|c|c|c|c|}
\hline Nanoclay & Electrode & $\begin{array}{l}\text { Functional } \\
\text { Molecule }\end{array}$ & Analyte & $\begin{array}{l}\text { Analytical Range } \\
(\mathrm{mM})\end{array}$ & LOD $(\mu \mathrm{M})$ & Ref. \\
\hline $\begin{array}{l}\text { Laponite and } \\
\text { Montmorillonite }\end{array}$ & ITO & Ionic liquids & $\begin{array}{l}\text { Organic acids, urea, } \\
\text { glucose or } \\
\text { cholesterol }\end{array}$ & - & - & [96] \\
\hline $\begin{array}{l}\text { Co/Al based } \\
\text { hydrotalcite }\end{array}$ & $\mathrm{Pt}$ & - & Salicylic acid & $\begin{array}{c}0.01 \text { to } 0.5 \text { and } 5 \times \\
10^{-4} \text { to } 0.1\end{array}$ & $\begin{array}{c}6 \\
0.2 \\
\end{array}$ & [94] \\
\hline HNTs & Carbon & Carbon & Niclosamide & - & - & [17] \\
\hline Montmorillonite & Carbon & Graphene oxide & Cefotaxime & $\begin{array}{c}5 \times 10^{-4} \text { to } 4 \times 10^{-3} \\
0.040 \text { to } 2.4\end{array}$ & $1 \times 10^{-4}$ & [95] \\
\hline
\end{tabular}

\subsection{Nanoclay-Based Optical Sensors}

Optical sensors rely on the changes of absorption or emission properties of a fluorophore upon interaction with a bioanalyte and provide high sensitivity [29]. Typically, organic molecules, gold NPs, and transition metal or lanthanide cations have been used as chromophores. In particular, the sharp-line $\mathrm{Eu}^{3+}$ luminescence is an ideal spectroscopic probe, since both the fine structure, the relative intensity of different $f-f$ transitions, and the lifetime are highly dependent on the local environment of $\mathrm{Eu}^{3+}$ ions [33]. In addition, colorimetric methods, which allow immediate detection by qualitative color change observed by the naked eye, have recently gained attention due to faster operation, low cost, and simplicity. A summary of the performance of different optical sensors based on fluorophores incorporated in nanoclays, such as laponite [97-101], montmorillonite [102-108] or LDH [109], is presented in Table 8. They can be classified as a function of the type of the detected bioanalyte, as exposed in the following paragraphs.

Table 8. Summary of the different nanoclay-based optical sensors for $\mathrm{H}_{2} \mathrm{O}_{2}$, protein, organic compounds, and bacteria detection.

\begin{tabular}{|c|c|c|c|c|c|c|c|}
\hline Nanoclay & Functional Molecule & Fluorophore & Analyte & Time & $\begin{array}{c}\text { Detection } \\
\text { Limit } \\
(\mu \mathrm{M})\end{array}$ & $\begin{array}{l}\text { Analytical Range } \\
\text { (mM) }\end{array}$ & Ref. \\
\hline Laponite & (ttfa)3(topo)2 & $\begin{array}{c}\mathrm{Eu}^{3+} \\
\text { Nile Red }\end{array}$ & $\begin{array}{c}\text { BSA } \\
\text { B-lactoglobulin }\end{array}$ & - & - & - & [97] \\
\hline Laponite & $\begin{array}{c}2- \\
\text { thenoyltrifluoroacetone }\end{array}$ & $\mathrm{Eu}^{3+}$ & CTAB & - & $0-100$ & $3.8 \times 10^{-6}$ & [98] \\
\hline Laponite & & Nile Red & СТАВ & - & - & - & [99] \\
\hline Laponite & DPA & $\mathrm{Eu}^{3+}$ & Glutathione & - & $0.5-30$ & $1.62 \times 10^{-4}$ & [100] \\
\hline Laponite & DPA & $\mathrm{Eu}^{3+}$ & Ascorbic acid & - & $0.5-20$ & $1 \times 10^{-4}$ & [101] \\
\hline Montmorillonite & - & Polymer dot & $\begin{array}{c}\text { E. coli and } S \text {. aureus } \\
\text { bacteria }\end{array}$ & - & $\begin{array}{c}10-10^{7} \\
\mathrm{CFU} / \mathrm{mL}\end{array}$ & $5.09-4.62$ CFU /mL & [102] \\
\hline Montmorillonite & - & $\begin{array}{l}\text { 6-(1,3-dioxo- } \\
\text { 1H-benzo[de]- } \\
\text { isoquinolin- } \\
\text { 2(3H)-yl) } \\
\text { hexanoic acid }\end{array}$ & $\begin{array}{c}\text { E. coli and } S \text {. aureus } \\
\text { bacteria }\end{array}$ & - & erer & - & [103] \\
\hline Montmorillonite & $\mathrm{CeO}_{2}$ & - & $\mathrm{H}_{2} \mathrm{O}_{2}$ & $<30 \mathrm{~s}$ & 7.8 & $9 \times 10^{-3}$ to 0.5 & [104] \\
\hline Montmorillonite & $\mathrm{CuS}$ & - & $\mathrm{H}_{2} \mathrm{O}_{2}$ & $30 \mathrm{~s}$ & 24.7 & 0.03 to 0.2 & [105] \\
\hline Montmorillonite & $\mathrm{ZnS}$ & - & $\mathrm{H}_{2} \mathrm{O}_{2}$ & $<30 \mathrm{~s}$ & 10.48 & 0.07-06 & [106] \\
\hline Montmorillonite & $\mathrm{CuS} / \mathrm{Co}^{+2}$ & - & $\mathrm{H}_{2} \mathrm{O}_{2}$ & & 2.2 & $0.01-0.1$ & [107] \\
\hline Montmorillonite & $\mathrm{CuO}_{2}-\mathrm{NP}$ & - & $\mathrm{H}_{2} \mathrm{O}_{2}$ & $30 \mathrm{~s}$ & 2.395 & $3 \times 10^{-3}$ to $8 \times 10^{-3}$ & [108] \\
\hline $\mathrm{LDH}$ & Pt NP & - & $\mathrm{H}_{2} \mathrm{O}_{2}$ & $30 \mathrm{~s}$ & 760 & $10-90$ & [109] \\
\hline
\end{tabular}

DPA: pyridine-2, 6-dicarboxylic acid; CTAB: cetyltrimethylammonium bromide.

Felbeck et al. developed a sensor based on two fluorescent probes incorporated in laponite hybrids to detect BSA and $\beta$-lactoglobulin by optical spectroscopy [97]. In particular, laponite hybrids were loaded with the fluorescent dye Nile Red, previously used for both proteins' analysis, and with the $\mathrm{Eu}^{3+}$ complex Eu(ttfa) ${ }_{3}$ (topo $)_{2}$, which has been successfully incorporated into silica hybrids. They demonstrated that, while addition of 
BSA or $\beta$-lactoglobulin to the surface of Nile Red-doped laponite led to a blue shift of the emission band and an increase in the luminescence intensity, the $\mathrm{Eu}^{3+}$-loaded nanoclays displayed a quenching of the $\mathrm{Eu}^{3+}$ emission, ascribed to substitution of a ttfa ligand by an amino acid of the protein.

A nano-hybrid luminescence sensor of surfactants in aqueous solution based on $\mathrm{Eu}^{3+}$ $\beta$-diketonate complexes and laponite was developed by Yang et al. [98]. Their results revealed that the $\mathrm{Eu}^{3+}$-2-Thenoyltrifluoroacetone@laponite system showed a fast, highly sensitive and selective detection for cationic surfactants. In particular, they showed that the $\mathrm{Eu}^{3+}$ luminescence intensity gradually increased for higher concentrations of CTAB, reaching its maximum for a concentration of $\mathrm{CTAB}$ of $5.5 \mathrm{mM}$. The estimated that the LOD for CTAB is $3.8 \mathrm{nM}$. In addition to the emission intensity, the $\mathrm{I}\left({ }^{5} \mathrm{D}_{0}-{ }^{7} \mathrm{~F}_{2}\right) / \mathrm{I}\left({ }^{5} \mathrm{D}_{0}-{ }^{7} \mathrm{~F}_{1}\right)$ intensity ratio also increased as the concentration of CTAB increased. Finally, the decay time increased from $0.31 \mathrm{~ms}$ to $0.50 \mathrm{~ms}$ as the concentrations of CTAB increased from 0 to $2.7 \mathrm{mM}$, due to a reduction of the coordination of water molecules, and an enhancement of the quantum yield from 13.4 to $36.5 \%$ was observed.

Similarly, Felbeck et al. [99] presented an exhaustive study of the optical properties of the Nile Red dye incorporated in laponite, in the absence and presence of the CTAB cationic surfactant. They demonstrated that, since the Nile Red optical properties are different for dispersions of both the unmodified and the CTAB-modified laponite, they can be employed as an optical probe in aqueous dispersion. Specifically, the shifts in the absorption and emission bands observed in the CTAB system compared to the original Nile Red-doped laponite was assigned to a less polar dye environment in the case of the CTAB-modified laponite.

Glutathione is an essential peptide that plays a significant role in several biological disorders such as Alzheimer or cardiovascular disease. Recently, a large body of research dealing with sensors able to distinguish glutathione from cysteine and homocysteine has emerged. Chen et al. [100] proposed the use of a hybrid material based on laponite and $\mathrm{Eu}^{3+}$ coordinated by pyridine-2, 6-dicarboxylic acid (DPA), denoted Eu(DPA)@Lapo, for selective detection of glutathione both in solution and within hydrogels. Briefly, since the Eu(DPA)@Lapo system shows intense luminescence, which is efficiently quenched upon addition of $\mathrm{Cu}^{2+}$ ions, they demonstrated that the presence of glutathione, which induces the removal of $\mathrm{Cu}^{2+}$ from the Eu(DPA)@Lapo, resulted in fluorescence recovery. The proposed assay demonstrated high selectivity toward glutathione and showed a detection limit of $162 \mathrm{nM}$ within a linear range of $0.5-30 \mu \mathrm{M}$.

Ascorbic acid also plays an essential role in many biochemical processes and it is considered to effectively scavenge reactive species to prevent oxidative damage. Chen et al. [101] proposed a nano-hybrid based on laponite and Eu and Gd DPA complexes, Gd(DPA)@Lapo and $\mathrm{Eu}(\mathrm{DPA}) / \mathrm{Gd}(\mathrm{DPA}) @$ Lapo, as a bimodal sensor with both magnetic resonance and fluorescence functionality (Figure 4). Firstly, regarding the application as magnetic resonance contrast agents, the calculated longitudinal relaxation rate was $12.36 \mathrm{mM}^{-1} \mathrm{~s}^{-1}$ for Gd(DPA)@Lapo and $8.41 \mathrm{mM}^{-1} \mathrm{~s}^{-1}$ for Eu(DPA)/Gd(DPA)@Lapo, which was higher than that from commercial agent Gd-DTPA, $4.63 \mathrm{mM}^{-1} \mathrm{~s}^{-1}$, at the same concentration. They demonstrated a linear dependence of the longitudinal relaxation time with the concentration of ascorbic acid in the 0.5 to $20 \mu \mathrm{M}$ range, with a LOD of $0.2 \mu \mathrm{M}$. Secondly, the fluorescence response of Eu(DPA)/Gd(DPA)@Lapo was also investigated. The relationship between the $\mathrm{Eu}^{3+}$ luminescence intensity and the ascorbic acid concentration showed a good linear correlation from 0.5 to $20 \mu \mathrm{M}$, and the LOD was calculated to be $0.1 \mu \mathrm{M}$. 


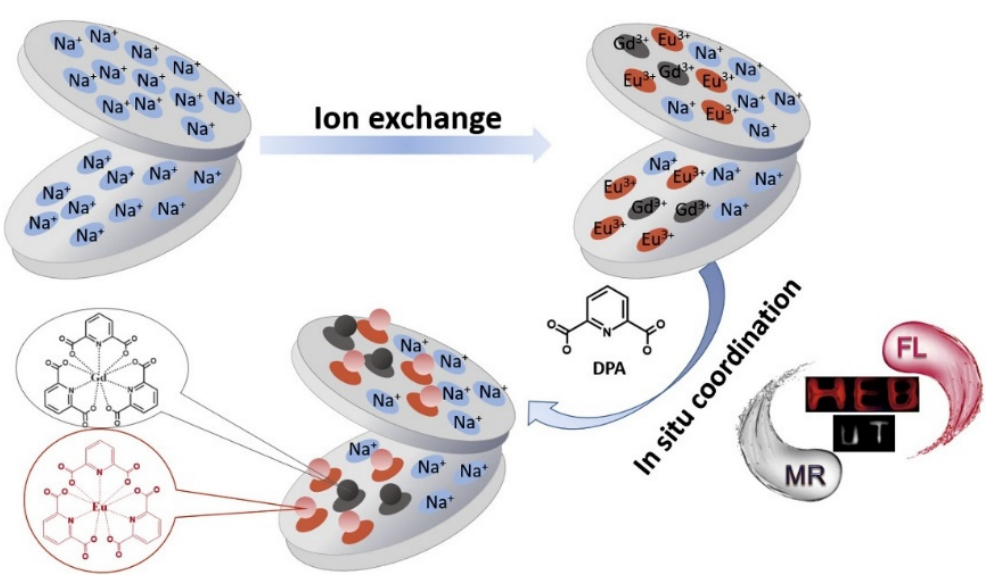

Figure 4. Schematic representation of the Eu(DPA)/Gd(DPA)@Lapo nanohybrid system. Reprinted with permission from ref. [101]. Copyright 2017 Elsevier.

Nanoclays, mainly montmorillonite, modified with different metal NPs or compounds have also been tested for $\mathrm{H}_{2} \mathrm{O}_{2}$ detection by colorimetric methods, as stated in Table 8 [104-108]. The response time for all these optical sensors was equal to or less than $30 \mathrm{~s}$, demonstrating the fast response to $\mathrm{H}_{2} \mathrm{O}_{2}$ detection of these nanoclay-based sensors. The detection limit was diverse and depended on the medium and metal used. In general, these values were higher than those observed with electrochemical sensors (see Table 6). LDH-based sensor exhibited by far the highest detection limit. In Figure 5, the schematic representation of a colorimetric sensing of $\mathrm{H}_{2} \mathrm{O}_{2}$ catalyzed by Co-doped CuS-montmorillonite is represented [107].

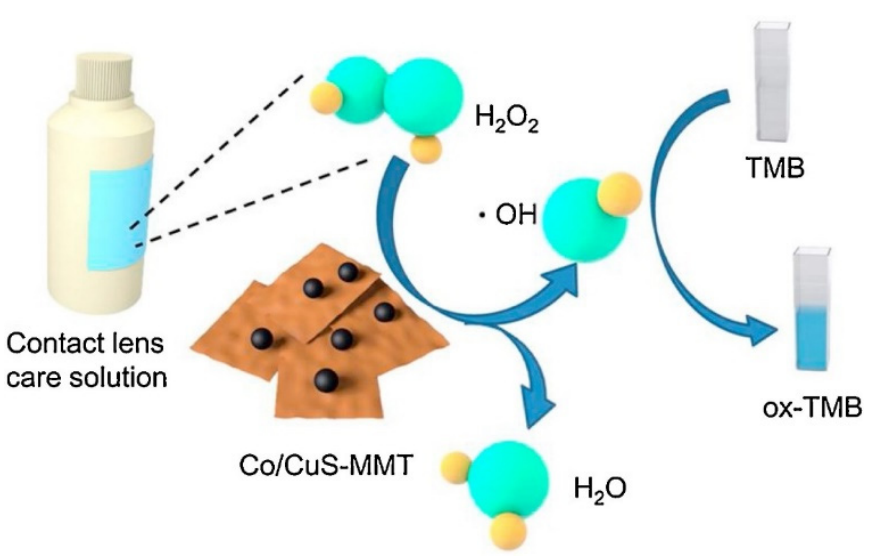

Figure 5. Schematic illustration of the colorimetric sensing of $\mathrm{H}_{2} \mathrm{O}_{2}$ catalyzed by Co-doped CuS-MMT. Reprinted with permission from [107]. Copyright 2020 Elsevier.

Recently, a large body of research has also focused on the development of new sensors to replace conventional methods for bacteria detection. In particular, the possibility of combining synergistic detection, antibacterial activity, and recyclability has gained attention. Robby et al. designed a fluorescent sensor with antibacterial activity by a two-step process involving (1) incorporation of an alkaline phosphatase-sensitive polymer dot, containing $\beta$-cyclodextrin, in montmorillonite, and (2) immobilization of magnetic iron oxide $\left(\mathrm{Fe}_{3} \mathrm{O}_{4}\right)$ and NIR-responsive cesium tungsten oxide $\left(\mathrm{CsWO}_{3}\right)$ [102]. This nanocomposite exhibited intense luminescence, which was quenched in the presence of bacterial alkaline phosphatase due to hydrolysis of p-nitrophenyl phosphate in the hydrophobic site of $\beta$-cyclodextrin. Additionally, the nanocomposite allowed detection of both Gram-negative Escherichia coli and Gram-positive Staphylococcus aureus in the range of $10-10^{7} \mathrm{CFU} / \mathrm{mL}$, with a LOD of 5.09 and $4.62 \mathrm{CFU} / \mathrm{mL}$, respectively, and showed high bacterial damage 
by inducing heat under NIR irradiation. This material also demonstrated recyclability via magnetic field exposure due to the presence of $\mathrm{Fe}_{3} \mathrm{O}_{4}$.

Silicate nanoplatelets derived from natural montmorillonite clay were used by Lin et al. as a platform to detect both Escherichia coli and Staphylococcus aureus bacteria [103]. Specifically, the silicate nanoplatelets were modified with hydrophilic poly(2-hydroxyethyl methacrylate) (PHEMA) hydrogels, widely used for biomedical applications. In this study, atom transfer radical polymerization was used to grow the PHEMA chains. Then the nathphalimide-type fluorescent 6-(1,3-dioxo-1H-benzo[de]- isoquinolin-2(3H)-yl)hexanoic acid was bonded for sensing applications.

In addition, several studies of cationic p-phenylene ethynylenes' oligomers have shown both antimicrobial activity and strong photophysical changes upon aggregation with potential use for sensing bacteria. Hill et al. [110] analyzed the adsorption of these oligomers on laponite and their results suggested that they induce aggregation of both oligomers and laponite discs, leading to changes of their optical properties and interactions with bacteria. Specifically, the formation of molecular aggregates on laponite induced a slight red shift of the main absorption band from $325 \mathrm{~nm}$ to $335 \mathrm{~nm}$ and the appearance of a new absorption band at $360 \mathrm{~nm}$, together with a red shift of the luminescence band from $370 \mathrm{~nm}$ to $430 \mathrm{~nm}$. Additionally, solid oligomers-laponite films were shown to have fair resistance to dissolution in aqueous solution compared with laponite alone, and adhesion and minor killing of both Gram-negative and Gram-positive bacteria on the surface was observed. The results of this study are useful for development of sensors and biocides involving laponite as a scaffold.

\section{Conclusions}

Nanoclays represent an important type of nanomaterials with unique layered structure and ion exchange capacity, and they hold great potential for new and existing applications, in particular for the development of new nanoclay-based sensors.

Regarding electrochemical detection methods, CLME have improved stability, linear response range, and sensitivity compared to existing electrodes. Moreover, the inclusion of organic molecules has opened new opportunities in the development of advanced electrodes. Particularly, biosensors based on the incorporation of enzymes into the nanoclay structure is destined to be an emerging technology for the detection of small metabolic molecules, mainly glucose. Additionally, optical detection methods using nanoclay-based sensors have increased in the latest years. In this sense, nanoclays have proven to be an optimal matrix for the incorporation of fluorophores' molecules with expecting applications to be found. However, a deeper analysis of the nanoclay role in the optical response would be desirable in order to design a specific optical sensor for a particular bioanalyte target.

Thus, nanoclays have shown that they can become a key factor in emerging technologies for sensor development, with application in both environmental and biomedical fields.

Author Contributions: All authors equally contributed to the conceptualization, bibliographic search, writing, reviewing, and editing of this manuscript. All authors have read and agreed to the published version of the manuscript.

Funding: This research received no external funding.

Institutional Review Board Statement: Not applicable.

Informed Consent Statement: Not applicable.

Data Availability Statement: Not applicable.

Acknowledgments: Pavón thanks University of Seville for the financial support of her current contract from VI PPIT-US program.

Conflicts of Interest: The authors declare no conflict of interest. 


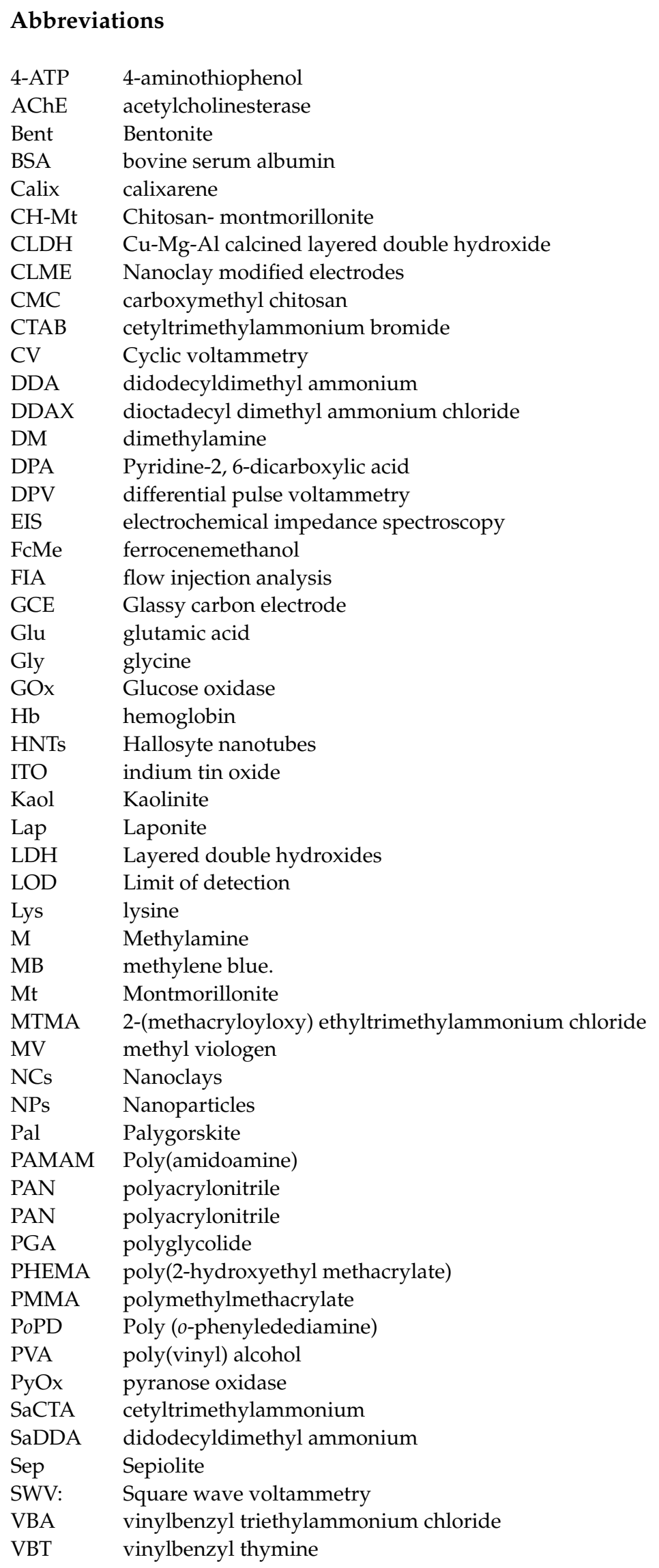




\section{References}

1. Official Journal of the European Union. Commission Recommendations; The European Commission: Brussels, Belgium, 2011; Volume 2011/696/E.

2. Bergaya, F.; Lagaly, G. Chapter 1-General Introduction: Clays, Clay Minerals, and Clay Science. In Handbook of Clay Science; Bergaya, F., Lagaly, G.B.T.-D., Eds.; Elsevier: Amsterdam, The Netherlands, 2013; Volume 5, pp. 1-19. ISBN $1572-4352$.

3. Mousty, C. Sensors and biosensors based on clay-modified electrodes-New trends. Appl. Clay Sci. 2004, 27, 159-177. [CrossRef]

4. Gianfreda, L.; Rao, M.A.; Sannino, F.; Saccomandi, F.; Violante, A. Enzymes in soil: Properties, behavior and potential applications. In Soil Mineral-Organic Matter-Microorganism Interactions and Ecosystem Health; Violante, A., Huang, P.M., Bollag, J.-M., Gianfreda, L.B.T.-D., Eds.; Elsevier: Amsterdam, The Netherlands, 2002; Volume 28, pp. 301-327, ISBN 0166-2481.

5. Wongkaew, N.; Simsek, M.; Griesche, C.; Baeumner, A.J. Functional Nanomaterials and Nanostructures Enhancing Electrochemical Biosensors and Lab-on-a-Chip Performances: Recent Progress, Applications, and Future Perspective. Chem. Rev. 2019, 119, 120-194. [CrossRef]

6. Karunakaran, C.; Madasamy, T.; Sethy, N.K. Chapter 3-Enzymatic Biosensors. In Biosensors and Bioelectronics; Karunakaran, C., Bhargava, K., Benjamin, R.B.T.-B., Eds.; Elsevier: Amsterdam, The Netherlands, 2015; pp. 133-204. ISBN 978-0-12-803100-1.

7. Suhito, I.R.; Koo, K.M.; Kim, T.H. Recent advances in electrochemical sensors for the detection of biomolecules and whole cells. Biomedicines 2021, 9, 15. [CrossRef] [PubMed]

8. Gao, L.L.; Gao, E.Q. Metal-organic frameworks for electrochemical sensors of neurotransmitters. Coord. Chem. Rev. 2021, 434, 213784. [CrossRef]

9. Zhou, Y.; Fang, Y.; Ramasamy, R. Non-Covalent Functionalization of Carbon Nanotubes for Electrochemical Biosensor Development. Sensors 2019, 19, 392. [CrossRef]

10. Huang, J.; Liu, Y.; Hou, H.; You, T. Simultaneous electrochemical determination of dopamine, uric acid and ascorbic acid using palladium nanoparticle-loaded carbon nanofibers modified electrode. Biosens. Bioelectron. 2008, 24, 632-637. [CrossRef]

11. Sajid, M.; Nazal, M.K.; Mansha, M.; Alsharaa, A.; Jillani, S.M.S.; Basheer, C. Chemically modified electrodes for electrochemical detection of dopamine in the presence of uric acid and ascorbic acid: A review. TrAC Trends Anal. Chem. 2016, 76, 15-29. [CrossRef]

12. Calò, S.; Curulli, A.; Zane, D.; Caschera, D.; Ingo, G.M.; Padeletti, G. Single Walled Carbon Nanotubes (SWCNTs)/Gold Nanoparticles (AuNps) Nanocomposites for Enhancing Electrochemical Response to Detect Neurotransmitters. ECS Trans. 2019, 25, 33-41. [CrossRef]

13. Zestos, A.G.; Jacobs, C.B.; Trikantzopoulos, E.; Ross, A.E.; Venton, B.J. Polyethylenimine carbon nanotube fiber electrodes for enhanced detection of neurotransmitters. Anal. Chem. 2014, 86, 8568-8575. [CrossRef] [PubMed]

14. Bouchta, D.; Izaoumen, N.; Zejli, H.; El Kaoutit, M.; Temsamani, K.R. Electroanalytical properties of a novel PPY $/ \gamma c y c l o d e x t r i n$ coated electrode. Anal. Lett. 2005, 38, 1019-1036. [CrossRef]

15. Kaur, B.; Srivastava, R. Synthesis of ionic liquids coated nanocrystalline zeolite materials and their application in the simultaneous determination of adenine, cytosine, guanine, and thymine. Electrochim. Acta 2014, 133, 428-439. [CrossRef]

16. Ghadiri, M.; Chrzanowski, W.; Rohanizadeh, R. Biomedical applications of cationic clay minerals. RSC Adv. 2015, 5, $29467-29481$. [CrossRef]

17. Zhao, H.; Chang, Y.; Liu, R.; Li, B.; Li, F.; Zhang, F.; Shi, M.; Zhou, L.; Li, X. Facile synthesis of Vulcan XC-72 nanoparticlesdecorated halloysite nanotubes for the highly sensitive electrochemical determination of niclosamide. Food Chem. 2021, 343, 128484. [CrossRef]

18. de Mello Ferreira Guimarães, A.; Ciminelli, V.S.T.; Vasconcelos, W.L. Surface modification of synthetic clay aimed at biomolecule adsorption: Synthesis and characterization. Mater. Res. 2007, 10, 37-41. [CrossRef]

19. El Kasmi, S.; Lahrich, S.; Farahi, A.; Zriouil, M.; Ahmamou, M.; Bakasse, M.; El Mhammedi, M.A. Electrochemical determination of paraquat in potato, lemon, orange and natural water samples using sensitive-rich clay carbon electrode. J. Taiwan Inst. Chem. Eng. 2016, 58, 165-172. [CrossRef]

20. Wagheu, J.K.; Forano, C.; Besse-Hoggan, P.; Tonle, I.K.; Ngameni, E.; Mousty, C. Electrochemical determination of mesotrione at organoclay modified glassy carbon electrodes. Talanta 2013, 103, 337-343. [CrossRef] [PubMed]

21. Manisankar, P.; Selvanathan, G.; Vedhi, C. Determination of pesticides using heteropolyacid montmorillonite clay-modified electrode with surfactant. Talanta 2006, 68, 686-692. [CrossRef] [PubMed]

22. Goda, E.S.; Gab-Allah, M.A.; Singu, B.S.; Yoon, K.R. Halloysite nanotubes based electrochemical sensors: A review. Microchem. J. 2019, 147, 1083-1096. [CrossRef]

23. An, N.; Zhou, C.H.; Zhuang, X.Y.; Tong, D.S.; Yu, W.H. Immobilization of enzymes on clay minerals for biocatalysts and biosensors. Appl. Clay Sci. 2015, 114, 283-296. [CrossRef]

24. Zoumpanioti, M.; Stamatis, H.; Xenakis, A. Microemulsion-based organogels as matrices for lipase immobilization. Biotechnol. Adv. 2010, 28, 395-406. [CrossRef] [PubMed]

25. Zhou, Z.; Hartmann, M. Progress in enzyme immobilization in ordered mesoporous materials and related applications. Chem. Soc. Rev. 2013, 42, 3894-3912. [CrossRef]

26. Holzinger, M.; Le Goff, A.; Cosnier, S. Carbon nanotube/enzyme biofuel cells. Electrochim. Acta 2012, 82, 179-190. [CrossRef] 
27. Serefoglou, E.; Litina, K.; Gournis, D.; Kalogeris, E.; Tzialla, A.A.; Pavlidis, I.V.; Stamatis, H.; Maccallini, E.; Lubomska, M.; Rudolf, P. Smectite clays as solid supports for immobilization of $\beta$-glucosidase: Synthesis, characterization, and biochemical properties. Chem. Mater. 2008, 20, 4106-4115. [CrossRef]

28. Tzialla, A.A.; Pavlidis, I.V.; Felicissimo, M.P.; Rudolf, P.; Gournis, D.; Stamatis, H. Lipase immobilization on smectite nanoclays: Characterization and application to the epoxidation of $\alpha$-pinene. Bioresour. Technol. 2010, 101, 1587-1594. [CrossRef] [PubMed]

29. Askim, J.R.; Suslick, K.S. Colorimetric and Fluorometric Sensor Arrays for Molecular Recognition. In Comprehensive Supramolecular Chemistry II; Atwood, J.L., Ed.; Elsevier Inc.: Amsterdam, The Netherlands, 2017; Volume 8, pp. 37-88. ISBN 9780128031988.

30. Wu, L.; Huang, C.; Emery, B.P.; Sedgwick, A.C.; Bull, S.D.; He, X.P.; Tian, H.; Yoon, J.; Sessler, J.L.; James, T.D. Förster resonance energy transfer (FRET)-based small-molecule sensors and imaging agents. Chem. Soc. Rev. 2020, 49, 5110-5139. [CrossRef] [PubMed]

31. Qin, S.J.; Yan, B. Dual-emissive ratiometric fluorescent probe based on Eu $\mathrm{u}^{3+} / \mathrm{C}$-dots@MOF hybrids for the biomarker diaminotoluene sensing. Sens. Actuators B Chem. 2018, 272, 510-517. [CrossRef]

32. Yang, G.; Zhao, J.; Yi, S.; Wan, X.; Tang, J. Biodegradable and photostable $\mathrm{Nb}_{2} \mathrm{C}$ MXene quantum dots as promising nanofluorophores for metal ions sensing and fluorescence imaging. Sens. Actuators B Chem. 2020, 309, 127735. [CrossRef]

33. Binnemans, K. Interpretation of europium(III) spectra. Coord. Chem. Rev. 2015, 295, 1-45. [CrossRef]

34. Zhang, X.; Jing, X.; Liu, T.; Han, G.; Li, H.; Duan, C. Dual-functional gadolinium-based copper(II) probe for selective magnetic resonance imaging and fluorescence sensing. Inorg. Chem. 2012, 51, 2325-2331. [CrossRef]

35. Barbosa, P.F.P.; Vieira, E.G.; Cumba, L.R.; Paim, L.L.; Nakamura, A.P.R.; Andrade, R.D.A.; do Carmo, D.R. Voltammetric techniques for pesticides and herbicides detection- an overview. Int. J. Electrochem. Sci. 2019, 14, 3418-3433. [CrossRef]

36. Van Der Werf, H.M.G. Assessing the impact of pesticides on the environment. Agric. Ecosyst. Environ. 1996, 60, 81-96. [CrossRef]

37. Du, D.; Chen, S.; Cai, J.; Zhang, A. Electrochemical pesticide sensitivity test using acetylcholinesterase biosensor based on colloidal gold nanoparticle modified sol-gel interface. Talanta 2008, 74, 766-772. [CrossRef]

38. Tchoumene, R.; Kenne Dedzo, G.; Ngameni, E. Preparation of Methyl Viologen-Kaolinite Intercalation Compound: Controlled Release and Electrochemical Applications. ACS Appl. Mater. Interfaces 2018, 10, 34534-34542. [CrossRef] [PubMed]

39. Mbokana, J.G.Y.; Dedzo, G.K.; Ngameni, E. Grafting of organophilic silane in the interlayer space of acid-treated smectite: Application to the direct electrochemical detection of glyphosate. Appl. Clay Sci. 2020, 188, 105513. [CrossRef]

40. Tcheumi, H.L.; Kameni Wendji, A.P.; Tonle, I.K.; Ngameni, E. A Low-Cost Layered Double Hydroxide (LDH) Based Amperometric Sensor for the Detection of Isoproturon in Water Using Carbon Paste Modified Electrode. J. Anal. Methods Chem. 2020, 2020. [CrossRef] [PubMed]

41. Laghrib, F.; Bakasse, M.; Lahrich, S.; El Mhammedi, M.A. Electrochemical sensors for improved detection of paraquat in food samples: A review. Mater. Sci. Eng. C 2020, 107, 110349. [CrossRef] [PubMed]

42. Abbaci, A.; Azzouz, N.; Bouznit, Y. A new copper doped montmorillonite modified carbon paste electrode for propineb detection. Appl. Clay Sci. 2014, 90, 130-134. [CrossRef]

43. Zhai, C.; Guo, Y.; Sun, X.; Zheng, Y.; Wang, X. An acetylcholinesterase biosensor based on graphene-gold nanocomposite and calcined layered double hydroxide. Enzyme Microb. Technol. 2014, 58-59, 8-13. [CrossRef] [PubMed]

44. Yanke, J.G.M.; Dedzo, G.K.; Ngameni, E. Solvent Effect on the Grafting of an Organophilic Silane Onto Smectite-type Clay: Application as Electrode Modifiers for Pesticide Detection. Electroanalysis 2017, 29, 1894-1902. [CrossRef]

45. Manisankar, P.; Selvanathan, G.; Vedhi, C. Utilization of sodium montmorillonite clay-modified electrode for the determination of isoproturon and carbendazim in soil and water samples. Appl. Clay Sci. 2005, 29, 249-257. [CrossRef]

46. Tcheumi, H.L.; Tonle, I.K.; Walcarius, A.; Ngameni, E. Electrocatalytic and Sensors Properties of Natural Smectite Type Clay towards the Detection of Paraquat Using a Film-Modified Electrode. Am. J. Anal. Chem. 2012, 03, 746-754. [CrossRef]

47. Zhao, D.; Zhao, L.; Zhu, C.S.; Shen, X.; Zhang, X.; Sha, B. Comparative study of polymer containing $\beta$-cyclodextrin and -COOH for adsorption toward aniline, 1-naphthylamine and methylene blue. J. Hazard. Mater. 2009, 171, 241-246. [CrossRef] [PubMed]

48. Grieshaber, D.; MacKenzie, R.; Vörös, J.; Reimhult, E. Electrochemical biosensors—Sensor principles and architectures. Sensors 2008, 8, 1400-1458. [CrossRef] [PubMed]

49. Oliveira, G.C.; Moccelini, S.K.; Castilho, M.; Terezo, A.J.; Possavatz, J.; Magalhães, M.R.L.; Dores, E.F.G.C. Biosensor based on atemoya peroxidase immobilised on modified nanoclay for glyphosate biomonitoring. Talanta 2012, 98, 130-136. [CrossRef]

50. Sarkar, T.; Narayanan, N.; Solanki, P.R. Polymer-Clay Nanocomposite-Based Acetylcholine esterase Biosensor for Organophosphorous Pesticide Detection. Int. J. Environ. Res. 2017, 11, 591-601. [CrossRef]

51. Phongphut, A.; Chayasombat, B.; Cass, A.E.G.; Sirisuk, A.; Phisalaphong, M.; Prichanont, S.; Thanachayanont, C. Clay/au nanoparticle composites as acetylcholinesterase carriers and modified-electrode materials: A comparative study. Appl. Clay Sci. 2020, 194. [CrossRef]

52. Flampouri, K.; Mavrikou, S.; Kintzios, S.; Miliadis, G.; Aplada-Sarlis, P. Development and validation of a cellular biosensor detecting pesticide residues in tomatoes. Talanta 2010, 80, 1799-1804. [CrossRef]

53. Jlassi, K.; Zavahir, S.; Kasak, P.; Krupa, I.; Mohamed, A.A.; Chehimi, M.M. Emerging clay-aryl-gold nanohybrids for efficient electrocatalytic proton reduction. Energy Convers. Manag. 2018, 168, 170-177. [CrossRef]

54. Dong, S.; Dao, A.Q.; Zheng, B.; Tan, Z.; Fu, C.; Liu, H.; Xiao, F. One-step electrochemical synthesis of three-dimensional graphene foam loaded nickel-cobalt hydroxides nanoflakes and its electrochemical properties. Electrochim. Acta 2015, 152, $195-201$. [CrossRef] 
55. Wang, Z.; Gui, M.; Asif, M.; Yu, Y.; Dong, S.; Wang, H.; Wang, W.; Wang, F.; Xiao, F.; Liu, H. A facile modular approach to the 2D oriented assembly MOF electrode for non-enzymatic sweat biosensors. Nanoscale 2018, 10, 6629-6638. [CrossRef]

56. Heller, A.; Feldman, B. Electrochemical Glucose Sensors and Their Applications in Diabetes Management. Chem. Rev. 2008, 108, 2482-2505. [CrossRef] [PubMed]

57. Yao, S.; Yuan, S.; Xu, J.; Wang, Y.; Luo, J.; Hu, S. A hydrogen peroxide sensor based on colloidal $\mathrm{MnO}_{2} / \mathrm{Na}^{-m o n t m o r i l l o n i t e . ~}$ Appl. Clay Sci. 2006, 33, 35-42. [CrossRef]

58. Sun, X.; Zhang, Y.; Shen, H.; Jia, N. Direct electrochemistry and electrocatalysis of horseradish peroxidase based on halloysite nanotubes/chitosan nanocomposite film. Electrochim. Acta 2010, 56, 700-705. [CrossRef]

59. Songurtekin, D.; Yalcinkaya, E.E.; Ag, D.; Seleci, M.; Demirkol, D.O.; Timur, S. Histidine modified montmorillonite: Laccase immobilization and application to flow injection analysis of phenols. Appl. Clay Sci. 2013, 86, 64-69. [CrossRef]

60. Seleci, M.; Ag, D.; Yalcinkaya, E.E.; Demirkol, D.O.; Guler, C.; Timur, S. Amine-intercalated montmorillonite matrices for enzyme immobilization and biosensing applications. RSC Adv. 2012, 2, 2112-2118. [CrossRef]

61. Han, X.; Zhu, Y.; Yang, X.; Li, C. Amperometric glucose biosensor based on platinum nanoparticle encapsulated with a clay. Microchim. Acta 2010, 171, 233-239. [CrossRef]

62. Unal, B.; Yalcinkaya, E.E.; Demirkol, D.O.; Timur, S. An electrospun nanofiber matrix based on organo-clay for biosensors: PVA/PAMAM-Montmorillonite. Appl. Surf. Sci. 2018, 444, 542-551. [CrossRef]

63. Sonmez, B.; Sayin, S.; Yalcinkaya, E.E.; Seleci, D.A.; Yildiz, H.B.; Demirkol, D.O.; Timur, S. Calixarene modified montmorillonite: A novel design for biosensing applications. RSC Adv. 2014, 4, 62895-62902. [CrossRef]

64. Demir, B.; Seleci, M.; Ag, D.; Cevik, S.; Yalcinkaya, E.E.; Demirkol, D.O.; Anik, U.; Timur, S. Amine intercalated clay surfaces for microbial cell immobilization and biosensing applications. RSC Adv. 2013, 3, 7513-7519. [CrossRef]

65. Demir, F.; Demir, B.; Yalcinkaya, E.E.; Cevik, S.; Demirkol, D.O.; Anik, U.; Timur, S. Amino acid intercalated montmorillonite: Electrochemical biosensing applications. RSC Adv. 2014, 4, 50107-50113. [CrossRef]

66. Maiga, M.; Yalcinkaya, E.E.; Sonmez, B.; Puglia, D.; Yavuz, M.; Demirkol, D.O.; Kenny, J.M.; Timur, S. CTAB modified dellite: A novel support for enzyme immobilization in bio-based electrochemical detection and its in vitro antimicrobial activity. Sens. Actuators B Chem. 2016, 235, 46-55. [CrossRef]

67. Luo, S.; Chen, Y.; Zhou, M.; Yao, C.; Xi, H.; Kong, Y.; Deng, L. Palygorskite-poly(o-phenylenediamine) nanocomposite: An enhanced electrochemical platform for glucose biosensing. Appl. Clay Sci. 2013, 86, 59-63. [CrossRef]

68. Unal, B.; Yalcinkaya, E.E.; Gumustas, S.; Sonmez, B.; Ozkan, M.; Balcan, M.; Demirkol, D.O.; Timur, S. Polyglycolidemontmorillonite as a novel nanocomposite platform for biosensing applications. New J. Chem. 2017, 41, 9371-9379. [CrossRef]

69. Yilmaz, Y.Y.; Yalcinkaya, E.E.; Demirkol, D.O.; Timur, S. 4-aminothiophenol-intercalated montmorillonite: Organic-inorganic hybrid material as an immobilization support for biosensors. Sens. Actuators B Chem. 2020, 307, 127665. [CrossRef]

70. Paz Zanini, V.I.; Gavilán, M.; López De Mishima, B.A.; Martino, D.M.; Borsarelli, C.D. A highly sensitive and stable glucose biosensor using thymine-based polycations into laponite hydrogel films. Talanta 2016, 150, 646-654. [CrossRef]

71. Emre, F.B.; Kesik, M.; Kanik, F.E.; Akpinar, H.Z.; Aslan-Gurel, E.; Rossi, R.M.; Toppare, L. A benzimidazole-based conducting polymer and a PMMA-clay nanocomposite containing biosensor platform for glucose sensing. Synth. Met. 2015, 207, 102-109. [CrossRef]

72. Apetrei, R.M.; Camurlu, P. The effect of montmorillonite functionalization on the performance of glucose biosensors based on composite montmorillonite/PAN nanofibers. Electrochim. Acta 2020, 353, 136484. [CrossRef]

73. Shi, Q.; Li, Q.; Shan, D.; Fan, Q.; Xue, H. Biopolymer-clay nanoparticles composite system (Chitosan-laponite) for electrochemical sensing based on glucose oxidase. Mater. Sci. Eng. C 2008, 28, 1372-1375. [CrossRef]

74. Coche-Guérente, L.; Desprez, V.; Labbé, P. Characterization of organosilasesquioxane-intercalated-laponite-clay modified electrodes and (bio)electrochemical applications. J. Electroanal. Chem. 1998, 458, 73-86. [CrossRef]

75. Poyard, S.; Jaffrezic-Renault, N.; Martelet, C.; Cosnier, S.; Labbe, P.; Besombes, J.L. A new method for the controlled immobilization of enzyme in inorganic gels (laponite) for amperometric glucose biosensing. Sens. Actuators B Chem. 1996, 33, 44-49. [CrossRef]

76. Asif, M.; Aziz, A.; Azeem, M.; Wang, Z.; Ashraf, G.; Xiao, F.; Chen, X.; Liu, H. A review on electrochemical biosensing platform based on layered double hydroxides for small molecule biomarkers determination. Adv. Colloid Interface Sci. 2018, 262, 21-38. [CrossRef] [PubMed]

77. Taviot-Guého, C.; Prévot, V.; Forano, C.; Renaudin, G.; Mousty, C.; Leroux, F. Tailoring Hybrid Layered Double Hydroxides for the Development of Innovative Applications. Adv. Funct. Mater. 2018, 28, 1-33. [CrossRef]

78. Tonelli, D.; Scavetta, E.; Giorgetti, M. Layered-double-hydroxide-modified electrodes: Electroanalytical applications. Anal. Bioanal. Chem. 2013, 405, 603-614. [CrossRef] [PubMed]

79. Gualandi, I.; Vlamidis, Y.; Mazzei, L.; Musella, E.; Giorgetti, M.; Christian, M.; Morandi, V.; Scavetta, E.; Tonelli, D. Ni/Al Layered Double Hydroxide and Carbon Nanomaterial Composites for Glucose Sensing. ACS Appl. Nano Mater. 2019, 2, 143-155. [CrossRef]

80. Wang, Y.; Peng, W.; Liu, L.; Tang, M.; Gao, F.; Li, M. Enhanced conductivity of a glassy carbon electrode modified with a graphene-doped film of layered double hydroxides for selectively sensing of dopamine. Microchim. Acta 2011, 174, 41-46. [CrossRef]

81. Patel, V.; Kruse, P.; Selvaganapathy, P.R. Solid State Sensors for Hydrogen Peroxide Detection. Biosensors 2020, 11, 9. [CrossRef] 
82. Andersen, B.M.; Rasch, M.; Hochlin, K.; Jensen, F.-H.; Wismar, P.; Fredriksen, J.-E. Decontamination of rooms, medical equipment and ambulances using an aerosol of hydrogen peroxide disinfectant. J. Hosp. Infect. 2006, 62, 149-155. [CrossRef]

83. Meier, J.; Hofferber, E.; Stapleton, J.A.; Iverson, N.M. Hydrogen peroxide sensors for biomedical applications. Chemosensors 2019, 7, 64. [CrossRef]

84. Yang, Z.; Zheng, X.; Zheng, J. Non-enzymatic sensor based on a glassy carbon electrode modified with Ag nanoparticles/polyaniline/halloysite nanotube nanocomposites for hydrogen peroxide sensing. RSC Adv. 2016, 6, 58329-58335. [CrossRef]

85. Zhang, S.; Sheng, Q.; Zheng, J. Synthesis of Ag-HNTs-MnO 2 nanocomposites and their application for nonenzymatic hydrogen peroxide electrochemical sensing. RSC Adv. 2015, 5, 26878-26885. [CrossRef]

86. Cao, H.; Sun, X.; Zhang, Y.; Jia, N. Electrochemical sensing based on gold nanoparticle-decorated halloysite nanotube composites. Anal. Biochem. 2012, 430, 111-115. [CrossRef] [PubMed]

87. Sheng, Q.; Zhang, D.; Wu, Q.; Zheng, J.; Tang, H. Electrodeposition of Prussian blue nanoparticles on polyaniline coated halloysite nanotubes for nonenzymatic hydrogen peroxide sensing. Anal. Methods 2015, 7, 6896-6903. [CrossRef]

88. Yadav, D.K.; Ganesan, V.; Gupta, R.; Yadav, M.; Sonkar, P.K.; Rastogi, P.K. Copper oxide immobilized clay nano architectures as an efficient electrochemical sensing platform for hydrogen peroxide. J. Chem. Sci. 2020, 132, 1-10. [CrossRef]

89. Yadav, D.K.; Gupta, R.; Ganesan, V.; Sonkar, P.K.; Rastogi, P.K. Electrochemical sensing platform for hydrogen peroxide determination at low reduction potential using silver nanoparticle-incorporated bentonite clay. J. Appl. Electrochem. 2016, 46, 103-112. [CrossRef]

90. Yan, P.; Zhong, L.; Wen, X.; Tang, A. Fabrication of $\mathrm{Cu}_{2} \mathrm{O} / \mathrm{TiO}_{2} /$ sepiolite electrode for effectively detecting of $\mathrm{H}_{2} \mathrm{O}_{2}$. J. Electroanal. Chem. 2018, 827, 1-9. [CrossRef]

91. Heli, H.; Pishahang, J.; Amiri, H.B. Synthesis of hexagonal CoAl-layered double hydroxide nanoshales/carbon nanotubes composite for the non-enzymatic detection of hydrogen peroxide. J. Electroanal. Chem. 2016, 768, 134-144. [CrossRef]

92. Yuan, J.; Xu, S.; Zeng, H.Y.; Cao, X.; Dan Pan, A.; Xiao, G.F.; Ding, P.X. Hydrogen peroxide biosensor based on chitosan/2D layered double hydroxide composite for the determination of $\mathrm{H}_{2} \mathrm{O}_{2}$. Bioelectrochemistry 2018, 123, 94-102. [CrossRef]

93. Charradi, K.; Gondran, C.; Amara, A.B.H.; Prévot, V.; Mousty, C. $\mathrm{H}_{2} \mathrm{O}_{2}$ determination at iron-rich clay modified electrodes. Electrochim. Acta 2009, 54, 4237-4244. [CrossRef]

94. Gualandi, I.; Scavetta, E.; Zappoli, S.; Tonelli, D. Electrocatalytic oxidation of salicylic acid by a cobalt hydrotalcite-like compound modified Pt electrode. Biosens. Bioelectron. 2011, 26, 3200-3206. [CrossRef]

95. Dehdashtian, S.; Behbahani, M.; Noghrehabadi, A. Fabrication of a novel, sensitive and selective electrochemical sensor for antibiotic cefotaxime based on sodium montmorillonite nonoclay/electroreduced graphene oxide composite modified carbon paste electrode. J. Electroanal. Chem. 2017, 801, 450-458. [CrossRef]

96. Joshi, N.; Sharma, A.; Rawat, K.; Asokan, K.; Solanki, P.R.; Lakshmi, G.B.V.S.; Kanjilal, D.; Bohidar, H.B. Comparative evaluation of enzyme-free nanoclay-ionic liquid based electrodes for detection of bioanalytes. RSC Adv. 2016, 6, 66120-66129. [CrossRef]

97. Felbeck, T.; Lezhnina, M.M.; Resch-Genger, U.; Kynast, U.H. Red emissive nanoclay hybrids in transparent aqueous dispersion-Towards optical applications in biophotonics. J. Lumin. 2016, 169, 728-732. [CrossRef]

98. Yang, D.; Wang, Y.; Wang, Y.; Li, H. A simple and effective luminescence sensor distinguishing cationic surfactants from other type of surfactants. Sens. Actuators B Chem. 2016, 235, 206-212. [CrossRef]

99. Felbeck, T.; Behnke, T.; Hoffmann, K.; Grabolle, M.; Lezhnina, M.M.; Kynast, U.H.; Resch-Genger, U. Nile-red-nanoclay hybrids: Red emissive optical probes for use in aqueous dispersion. Langmuir 2013, 29, 11489-11497. [CrossRef] [PubMed]

100. Chen, X.; Wang, Y.; Chai, R.; Xu, Y.; Li, H.; Liu, B. Luminescent Lanthanide-Based Organic/Inorganic Hybrid Materials for Discrimination of Glutathione in Solution and within Hydrogels. ACS Appl. Mater. Interfaces 2017, 9, 13554-13563. [CrossRef] [PubMed]

101. Chen, X.; Xu, Y.; Li, H.; Liu, B. A nanoclay-based magnetic/fluorometric bimodal strategy for ascorbic acid detection. Sens. Actuators B Chem. 2017, 246, 344-351. [CrossRef]

102. Robby, A.I.; Park, S.Y. Recyclable metal nanoparticle-immobilized polymer dot on montmorillonite for alkaline phosphatase-based colorimetric sensor with photothermal ablation of Bacteria. Anal. Chim. Acta 2019, 1082, 152-164. [CrossRef]

103. Lin, H.C.; Lin, J.J.; Sheng, Y.J. Interaction of Novel Fluorescent Nanoscale Ionic Silicate Platelets with Biomaterials for Biosensors. ACS Appl. Mater. Interfaces 2015, 7, 10771-10778. [CrossRef] [PubMed]

104. Sun, L.; Ding, Y.; Jiang, Y.; Liu, Q. Montmorillonite-loaded ceria nanocomposites with superior peroxidase-like activity for rapid colorimetric detection of $\mathrm{H}_{2} \mathrm{O}_{2}$. Sens. Actuators B Chem. 2017, 239, 848-856. [CrossRef]

105. Zhang, L.; Chen, M.; Jiang, Y.; Chen, M.; Ding, Y.; Liu, Q. A facile preparation of montmorillonite-supported copper sulfide nanocomposites and their application in the detection of $\mathrm{H}_{2} \mathrm{O}_{2}$. Sens. Actuators B Chem. 2017, 239, 28-35. [CrossRef]

106. Ding, Y.; Sun, L.; Jiang, Y.; Liu, S.; Chen, M.; Chen, M.; Ding, Y.; Liu, Q. A facile strategy for the preparation of ZnS nanoparticles deposited on montmorillonite and their higher catalytic activity for rapidly colorimetric detection of $\mathrm{H}_{2} \mathrm{O}_{2}$. Mater. Sci. Eng. C 2016, 67, 188-194. [CrossRef] [PubMed]

107. Wu, K.; Li, W.; Zhao, S.; Chen, W.; Zhu, X.; Cui, G.; Liu, Z.; Liu, Q.; Zhang, X.; Zhang, X. Cobalt tuned copper sulfide on montmorillonite: Peroxidase-like activity, catalytic mechanism and colorimetric sensing of hydrogen peroxide. Colloids Surfaces A Physicochem. Eng. Asp. 2020, 602, 125063. [CrossRef] 
108. Lian, S.; Gao, L.; Chen, M.; Liu, Z.; Qiu, J.; Zhang, X.; Luo, X.; Zeng, R.; Liu, Q. Enhanced peroxidase-like activity of MMTsupported cuprous oxide nanocomposites toward rapid colorimetric estimation of $\mathrm{H}_{2} \mathrm{O}_{2}$. Appl. Organomet. Chem. 2019, 33, 1-10. [CrossRef]

109. Cao, X.; Yang, H.; Wei, Q.; Yang, Y.; Liu, M.; Liu, Q.; Zhang, X. Fast colorimetric sensing of $\mathrm{H}_{2} \mathrm{O}_{2}$ and glutathione based on Pt deposited on $\mathrm{NiCo}$ layered double hydroxide with double peroxidase-/oxidase-like activity. Inorg. Chem. Commun. 2021, 123. [CrossRef]

110. Hill, E.H.; Zhang, Y.; Whitten, D.G. Aggregation of cationic p-phenylene ethynylenes on Laponite clay in aqueous dispersions and solid films. J. Colloid Interface Sci. 2015, 449, 347-356. [CrossRef] 